\title{
A NOÇÃO DE PRIVACY NA JURISPRUDÊNCIA DA SUPREMA CORTE NORTE-AMERICANA: EXISTE UM CONCEITO UNIFICADOR?
}

\author{
THE NOTION OF PRIVACY IN THE US SUPREME COURT CASE-LAW: IS THERE A \\ UNIFYING CONCEPT?
}

\section{Eugênio Facchini Neto}

Doutor em Direito Comparado (Florença/Itália); Mestre em Direito Civil pela Universidade de São Paulo; Professor Titular dos Cursos de Graduação, Mestrado e Doutorado em Direito na Pontifícia Universidade Católica do Rio Grande do Sul; Professor e ex-diretor da Escola Superior da Magistratura/Ajuris; Desembargador do Tribunal de Justiça do Estado do Rio Grande do Sul. E-mail: facchini@ @irs.jus.br

Recebido em: 11/09/2019

Aprovado em: 30/05/2020

RESUMO: A privacy é uma noção relativamente recente no mundo do direito, pois somente no final do século XIX ela passou a chamar a atenção do mundo jurídico. Algumas décadas depois ela passou a ser invocada como fundamento para o julgamento de determinados casos. No início, tratava-se de tema ausente do direito constitucional, mais analisado sob o prisma dos direitos de personalidade, normalmente envolvendo demandas de responsabilidade civil. Nos Estados Unidos, porém, já na década de vinte o tema ganhou coloração constitucional, passando a ser paulatinamente invocado em situações muito diversas entre si, como casamento, procriação, contracepção, relações familiares, criação e educação de filhos, invalidação de provas em processo criminal, relações homossexuais, crime de sodomia, etc. Uma das razões de tamanha amplitude aplicativa está ligada ao conceito polimorfo e fluído de privacy. Objetivo desse artigo é traçar a origem e evolução do conceito de privacy na cultura jurídica norte-americana, através da jurisprudência de sua Suprema Corte. Perceber-se-á que não só é vago o referido conceito, como igualmente é controvertida a base constitucional a partir da qual se pode extrair aquela noção e aparentemente inexiste um ideia unificadora. Todavia, apesar de sua invocação para fundamentar casos muito díspares entre si, ela permanece uma noção importante, tendo perpassado a jurisprudência do século XX e adentrado o novo milênio. Privilegiou-se a utilização do método dialético, lançando-se mão de pesquisa bibliográfica doutrinária e da jurisprudência da Suprema Corte norte-americana, com abordagem qualitativa.

Palavras-chave: Privacy. Conceito. Estados Unidos. Jurisprudência. Suprema Corte.

ABSTRACT: Privacy is a relatively recent notion in the world of law, as it was not until the late nineteenth century that it began to draw the attention of doctrine. In jurisprudence, it is only in the twentieth century that it is invoked as the basis for judging certain cases. In the beginning, it was an issue that was absent from constitutional law, but analyzed from the perspective of personality rights, usually present in discussions about civil liability. In the United States, however, in the 1920s, the subject gained constitutional coloration and was invoked in very different situations, 
such as marriage, procreation, contraception, family relations, child rearing, invalidation of evidence in criminal proceedings, gay relationships, crime of sodomy, etc. One of the reasons for such wide application is linked to the polymorphic and fluid concept of privacy. The purpose of this article is to trace the origin and evolution of the concept of privacy, especially in the American legal culture, through the jurisprudence of its Supreme Court. It will be noted that not only is the concept of privacy vague in US case law, but the constitutional basis on which that notion can be derived is also controversial. The use of the dialectical method was privileged, using the doctrinal bibliographic research and the jurisprudence of the American Supreme Court, with a qualitative approach.

Keywords: Privacy. Conceito. Estados Unidos. Jurisprudência. Suprema Corte.

SUMÁRIO: Introdução. 1 Privacy - surgimento e evolução de um conceito. 2 A privacy nos Estados Unidos - aspectos doutrinários. 3 A privacy recepcionada pela jurisprudência norteamericana. 3.1 Meyer v. Nebraska (1923). 3.2 Olmstead v. United States (1928). 3.3 NAACP v. Alabama (1958). 3.4 Katz v. United States (1967). 3.5 Griswold v. Connecticut (1965). 3.6 Eisenstadt v. Baird (1972). 3.7 Carey v. Population Services Int'1 (1977). 3.8 Casuística posterior. Considerações finais. Referências.

\section{INTRODUÇÃO}

Nos Estados Unidos, o tema da privacy foi introduzido por influente artigo doutrinário publicado em 1890. Na década de vinte do século passado, a Suprema Corte proferiu dois julgamentos em que fez precoce alusão ao mesmo. Essas menções esporádicas passaram a ser mais consistentes a partir da década de cinquenta e, de forma central, a partir da década de sessenta. Efeitos dessa discussão se prolongaram em importantes casos julgados nas décadas posteriores e até neste milênio.

O mesmo tema também esteve presente ao longo do século XX em importantes decisões de tribunais dos mais variados países ${ }^{1}$, como a Alemanha, França, da Corte Europeia de Direitos Humanos, bem como em países de tradições jurídicas tão distintas quanto a Colômbia e a África do Sul, como será sucintamente indicado. Mas o objeto principal deste estudo diz respeito à gênese e evolução do conceito de privacy e sua aplicação pela jurisprudência da Suprema Corte norteamericana. Procurar-se-á demonstrar que a ausência de previsão normativa expressa não é obstáculo para que determinadas concepções jurídicas venham a ser reconhecidas e aplicadas jurisprudencialmente, quando elas estiverem em consonância e harmonia com a tradição jurídica e com os valores da sociedade em que operam os juízes.

A análise dos casos selecionados permitirá ao leitor perceber que não há uma noção homogênea de privacy na experiência judiciária norte-americana De fato, refletindo sua noção fluída, as aplicações da ideia de privacy - identificada como direito fundamental não expressamente previsto na Constituição norte-americana -, perpassaram temas como gravações de conversas telefônicas, o direito dos genitores de decidirem livremente sobre como educar seus filhos, o direito de casais de livremente optarem por formas de controle de natalidade, aborto por opção da gestante, práticas sexuais homossexuais e casamento homossexual, dentre outros. Embora haja aspectos comuns que subjazem a essas aplicações, a aplicação jurisprudencial reflete as diversas concepções doutrinárias sobre privacy.

\footnotetext{
${ }^{1}$ Não estamos considerando o caso Rachel, julgado em 1858, pelo Tribunal civil de la Seine, na França, no qual pela primeira vez foi protegido o direito à imagem (envolvia a reprodução de uma fotografia da então famosa artista francesa, em seu leito de morte), nem o caso envolvendo a reprodução fotográfica da máscara mortuária de Otto Von Bismarck, julgado em 1898, na Alemanha, pois ambos os casos são referidos como precoces exemplos de proteção do direito à imagem, como direito autônomo de personalidade - Sobre esses casos, v. Facchini (2018, p. 288 e seq.).

Revista de Direito Brasileira | Florianólopis, SC | v. 25 | n. 10 | p. 414-440 | Jan./Abr. 2020
} 
A casuística analisada também permitirá ao leitor tomar consciência de algumas peculiaridades e idiossincrasias da cultura norte-americana. Em razão das limitações espaciais desse artigo, trata-se mais de estudo de direito estrangeiro do que propriamente um estudo de direito comparado, pois serão breves as pontuais comparações realizadas.

Para permitir uma análise minimamente aprofundada da casuística pertinente, optou-se por deixar para estudos separados, que estão sendo concomitantemente ultimados, a análise dos importantes acórdãos envolvendo a espinhosa questão do aborto e da homossexualidade, no cenário norte-americano, abordadas nos casos Roe v. Wade (1973), Planned Parenthood of Southeastern Pennsylvania v. Casey (1992), Whole Woman's Health v. Hellerstedt (2016), Bowers v. Hardwick (1986), Lawrence v. Texas (2003) e Obergefell v. Hodges (2015), dentre os mais importantes. Tais acórdãos normalmente apoiam-se também na noção de proteção da privacy, mas, como explicado, as limitações espaciais desse artigo impedem que sejam também aqui considerados, pois sua importância exigiria um aprofundamento mínimo, como se procurará fazer com os casos selecionados para este estudo.

O estudo inicia pela análise de aspectos conceituais da privacy, indicando-se os estudos iniciais e a evolução de sua noção, nos Estados Unidos e no ambiente europeu. A parte principal do estudo, porém, diz respeito à análise aprofundada de sete acórdãos proferidas pela Suprema Corte norte-americana, nas décadas de vinte e nas décadas de cinquenta a setenta. Durante a análise mais aprofundada desses acórdãos selecionados, far-se-á breve referência a outras decisões que guardam pertinência com aqueles.

O problema que se coloca é saber se se existe uma racionalidade que acomune a aplicação da privacy pela Suprema Corte dos Estados Unidos. Para enfrentar esse problema, foi utilizado o método dialético, lançando-se mão de pesquisa bibliográfica doutrinária e jurisprudencial, examinando-se jurisprudência selecionada da suprema corte norte-americana em que a noção da privacy foi invocada como principal ou uma das razões de decidir, em ordem cronológica, com abordagem qualitativa.

\section{PRIVACY - SURGIMENTO E EVOLUÇÃO DE UM CONCEITO}

Do ponto de vista doutrinário, uma das dificuldades do tema é que se trata de um conceito "polimorfo, protéico e heteróclito, cujo conteúdo é imprevisível” (MEULDERS-KLEIN: 1992, p. 767) e "não suscetível de uma definição exaustiva"2. Discute-se inclusive se consiste em uma noção única, embora protegendo uma multiplicidade de aspectos relacionados entre si, ou se, ao contrário, configura uma série de direitos diversos e não relacionados.

Pioneiros no estudo sobre a privacy, Warren e Brandeis (1890) entendiam-na como um direito à não intrusão, ou seja, o direito a não ser perturbado ou o direito a ser deixado só - the right to be let alone. Essa visão "abriu o caminho para a associação entre privacidade e liberdade" (RODOTÀ: 2008, p. 16).

Uma noção próxima a esta remonta a Hannah Arendt, que a identificava como possibilidade de exclusão, ou seja, o direito de excluir outros de nossa vida, e consequentemente de vivermos isolados, se o desejarmos, em paz e tranquilidade ${ }^{3}$.

\footnotetext{
${ }^{2}$ De acordo com a dicção da European Court of Human Rights, no caso Pretty v. United Kingdom (Ap. N. 2346/02, 2002-III).

${ }^{3}$ Trata-se, aqui, daquela noção que Hannah Arendt, na sua "A condição humana”, afirmou estar regida pelo princípio da exclusividade, ou seja, do direito do indivíduo criar para si um círculo abrangendo o que lhe é próprio, dele excluindo terceiros. Tal noção implicaria três atributos principais - o direito de estar só e de ser deixado só (noção clássica de privacidade), o sigilo ou segredo, e a autonomia, ou seja, a liberdade de decidir sobre todas as coisas que lhe dizem respeito, sem qualquer condicionamento ou influência, seja do Estado ou da sociedade. Reportando-se a tal noção, Tércio Sampaio Ferraz Jr. diferencia o espaço público-político do social-privado referindo que aquele é dominado pelo princípio da transparência e da igualdade; enquanto este está sob o domínio do princípio da diferenciação (no sentido

Revista de Direito Brasileira | Florianólopis, SC | v. 25 | n. 10 | p. 414-440 | Jan./Abr. 2020
} 
Outros autores, como Gavison (1980), Parent (1983, p. 4) e Allen (1988), passaram a definir privacy como limitação ${ }^{4}$. Seria a zona em que o acesso à informação pessoal poderia ser limitado ou restringido. A privacy perfeita ocorreria quando ninguém tivesse informações sobre um sujeito determinado.

Reagindo a essa última concepção, Fried (1990, p. 54) lançou a idéia de privacy como controle, segundo a qual a privacy não seria a simples ausência de informações sobre nós, por parte dos outros, mas sim o controle sobre a informação que os outros podem ter sobre nós.

Historiando a evolução do conceito de privacy, Rodotà (2008, p. 15) refere que Westin passou a sustentar que a privacidade incorporou o direito a controlar a maneira pela qual os outros utilizam as informações a nosso respeito e Friedman passou a defini-la como proteção de escolhas de vida contra qualquer forma de controle público e estigma social.

Na visão de Espinosa (2012, p. 969 e 970), o conceito de privacy evoluiu do simples right to be let alone para abranger situações bem mais amplas, como o direito de alguém de definir e construir sua própria identidade ${ }^{5}$, não só isoladamente, mas também em suas relações sociais, razão pela qual se costuma distinguir uma individual privacy de uma social privacy. ${ }^{6}$ Além disso, o mesmo autor refere ser possível identificar dois aspectos da privacy - um representa um direito negativo, que protege a pessoa de intrusões externas, de observações indesejadas, de coleta de informações a seu respeito, que não sejam motivadas por motivos legítimos, provenham essas ameaças ou lesões do Governo, ou de particulares. Mas é também possível identificar um direito positivo, que procura garantir ao indivíduo a construção de sua própria identidade e escolha de seu modo de viver. Sob esse ângulo, está o Estado compelido a criar condições propícias para tanto, removendo obstáculos para essa formatação autônoma da identidade individual mesmo contra interferências indevidas oriundas de outros particulares ${ }^{7}$.

Depois de referir também as concepções de privacy como algo que ficaria entre acesso restrito e controle limitado, ou privacy como informação, Pagallo (2008), acentua a dificuldade de se chegar a um consenso universal sobre o significado de privacy, em razão do fenômeno do multiculturalismo. Refere ele a inexistência de enfoques convergentes sobre o significado,

do direito de ser diferente); por fim, o terreno da individualidade privativa é regido pelo princípio da exclusividade (FERRAZ JÚNIOR: 1993, p. 441/442).

${ }^{4}$ Apud Facchini Neto (2009-a).

${ }^{5}$ Fazendo escolhas que digam respeito à sua identidade e maneira de viver, tomar decisões que se refiram à sua orientação sexual (como nos casos julgado pela Indian Supreme Court, no caso Gobind v. State of MP, em 1975; pela South African Constitutional Court, no caso National Coalition for Gay and lesbian Equality v Minister of Justice, em 1999; e pela Corte Constitucional da Colômbia, no caso C-481/1998), sua identidade sexual (como no caso julgado pela Corte Constitucional colombiana em 1999 (caso SU-337/1999), que garantiu a uma criança hermafrodita o direito de escolher qual identidade sexual iria adotar) e ao aborto (caso Roe v. Wade, julgado pela Suprema Corte norteamericana em 1973) - todos esses casos foram citados por Espinosa (2012), p. 970, notas 34 a 36.

${ }^{6}$ A Corte Constitucional alemã já em 1954 havia alertado que "a imagem de ser humano subjacente à Lei Fundamental não é a de um indivíduo isolado e soberano" (BVerfG, 20/07/1954).

${ }^{7}$ Aspectos esses que podem ser exemplificadas por duas decisões da Corte Constitucional colombiana, uma proibindo a expulsão de estudantes grávidas de escolas católicas (Acórdão n. T-393/1997), e outra proibindo a imposição de um específico corte de cabelo a estudantes (Acórdão n. SU-642/1998). Mas também pode ser exemplificado por decisão da Corte Constitucional alemã, de 1979, em caso envolvendo a mudança de sexo, que em nome do livre desenvolvimento da personalidade, impediu que autoridades públicas cumprissem mandamento legal que as obrigava a registrar a mudança de sexo no documento de identidade do reclamante. De acordo com a ECtHR, os Estados europeus são obrigados a editar legislação hábil e eficiente contra o estupro, para salvaguardar o direito á vida privada, mesmo quando a vítima não tenha feito queixa de violência física (caso MC v. Bulgária, Ap. n. 39272/98); os Estados deveriam providenciar um procedimento célere para permitir que uma criança pudesse descobrir suas origens biológicas (caso Mikulic v. Croatia, Ap. n. 53176/99); os Estados devem fornecer aos presos o material necessário para que possam se corresponder com outras pessoas (caso Cotlet v. Romania, Ap. n. 38565/97). Todavia, de forma surpreendente, também em nome da privacy, a Corte Europeia de Direitos Humanos, embora tenha reconhecido anteriormente que os Estados deveriam facilitar a identificação do pai natural, recusaram-se a reconhecer a mesma obrigação em relação à mãe, por ter ela optado por conceber um filho anonimamente (caso Odièvre v. France, Ap. n. 42326/98 - Grand Chamber, 2003-III) - sobre todos esses casos, v. Espinosa (2012, p. 970, 976/977).

Revista de Direito Brasileira | Florianólopis, SC | v. 25 | n. 10 | p. 414-440 | Jan./Abr. 2020 
realidade, extensão e importância da privacy em culturas distintas como a norte-americana, europeia, chinesa, japonesa e islâmica.

Na segunda metade da década de sessenta, a privacy representou o fundamento utilizado para o julgamento de importantes casos, tanto nos Estados Unidos, quanto na Europa. Efetivamente, nos Estados Unidos, a ascensão da privacy ao debate constitucional deu-se com o julgamento do caso Griswold v. Connecticut, pela Suprema Corte, em 1965. Na Europa, a Corte Europeia de Direitos Humanos, ao julgar o caso Belgian Linguistic Case em 1968, decidiu que o art. $8^{\circ}$ da Convenção Europeia, ao prever o direito à vida privada e familiar, garantia o direito do indivíduo contra interferências arbitrárias de autoridades públicas em sua vida privada e familiar. Em 1969 foi a vez da Corte Constitucional alemã, ao julgar o emblemático caso Microcensus, onde afirmou que o Estado tem o dever de deixar o indivíduo com um espaço próprio onde possa desenvolver de forma livre e responsável a sua personalidade. Dentro desse espaço, o indivíduo é seu próprio chefe.

$\mathrm{Na}$ França, isso ocorreu um pouco mais tarde. Embora a França tenha alterado seu Código Civil em 1970, para nele incluir a previsão do direito ao respeito à vida privada, foi somente em 1995 que o Conselho Constitucional reconheceu um direito constitucional à vida privada, ao julgar o caso Videosurveillance (no qual vinculou a privacidade ao anonimato, segredo e inviolabilidade do domicílio).

Os Estados Unidos normalmente identificam na privacy um "right of the individual to decide for himself" (WESTIN: 1970, p. 37), ao passo que a "Alemanha, Colômbia ${ }^{8}$ e África do $\mathrm{Sul}^{9}$ fazem derivar a privacidade do princípio da dignidade humana" (ESPINOSA: 2012, p. 968). Segundo outro autor, enquanto a privacy é analisada como um instituto praticamente autônomo nos Estados Unidos, nos países de tradição romano-germânica o seu estudo é normalmente feito dentro dos chamados direitos da personalidade (CABRILLAC: 2017, p. 226 e seq.).

Numa escala global, percebe-se que a partir dos anos 60, com a aceleração do desenvolvimento tecnológico, e com a possibilidade inaugurada com a revolução informática de se recolher e agrupar dados pessoais, houve uma ampliação do conceito de privacidade, que passou a envolver também a proteção aos dados e informações pessoais. Aliás, esse é o enfoque predominante hoje nas discussões acadêmicas e preocupações regulatórias estatais. Esse artigo, porém, não abordará esse outro importante tema, pois a análise jurisprudencial que faremos envolve noções diversas da privacidade.

\section{A PRIVACY NOS ESTADOS UNIDOS - ASPECTOS DOUTRINÁRIOS}

A proteção da privacidade não foi expressamente prevista na Constituição norteamericana de 1787 e nem no Bill of Rights, o conjunto das dez primeiras Emendas à Constituição, promulgadas dois anos após a Constituição. Também não fora previsto, aliás, na Declaração francesa de Direitos do Homem e do Cidadão, de 1789. A razão é simples. Naquela época, em que a maioria da população vivia pacatamente na zona rural, não se sentia a necessidade de proteger algo que não sofria ameaças. A situação começou a mudar à medida que progressivamente mais pessoas passaram a conviver em conglomerados urbanos e quando a imprensa percebeu que havia mercado para notícias sobre a vida privada de políticos, artistas, atletas, magnatas - e quanto mais íntimas e potencialmente escandalosas, melhor. Quando avanços tecnológicos permitiram câmaras fotográficas portáteis e, posteriormente, meios de gravação de conversas, as ameaças surgiram - e com isso a necessidade de proteção da privacy (KOOPMANS, 2005, p. 225). ${ }^{10}$

\footnotetext{
${ }^{8}$ Conforme decisão da Corte Constitucional da Colômbia, em 1993 - Acórdão T-413/1993.

${ }^{9}$ Conforme decisão da Corte Constitucional sul-africana, em 2002 - S v Jordan, 2002 (6) SA 642 (CC), § 81.

${ }^{10}$ Foram justamente essas mudanças que fizeram com que várias constituições mais recentes, de diversas tradições jurídicas, previssem expressamente a proteção da privacidade em seus textos, como é o caso da brasileira ("são invioláveis a intimidade, a vida privada..."), da sul-africana ("everyone has the right to privacy") e da sul-coreana ("the Revista de Direito Brasileira | Florianólopis, SC | v. 25 | n. 10 | p. 414-440 | Jan./Abr. 2020
} 
$\mathrm{O}$ direito à privacidade foi originariamente sustentado na doutrina norte-americana em 1890, denominado The Right to Privacy, como um direito à "não intrusão", ou seja, o direito a não ser perturbado. Seus autores foram Brandeis e Warren (1890) (Brandeis posteriormente viria a integrar a Suprema Corte, de 1916 a 1939). Os dois eram sócios de um renomado escritório de advocacia de Boston. Warren havia casado com a socialite Mabel Bayard, filha do Senador Thomas Bayard. Os jornais estavam permanentemente atrás do casal, em busca de matéria para suas colunas sociais. Mabel era frequentemente fotografada pelos repórteres, que utilizavam uma inovação tecnológica da época - as máquinas fotográficas portáteis. Os dois, então, escreveram o referido artigo, a fim de defenderem a existência de um right to privacy, segundo o qual a invasão da privacidade alheia não podia ser tolerada. Na ausência de legislação, doutrina ou precedentes específicos, procuraram eles demonstrar que o direito à privacidade era consistente com os princípios da Common Law, que deveria, portanto, estender sua proteção ao right to be let alone (direito de estar só). Referido artigo teve uma importância extraordinária ${ }^{11}$, ao focar as mudanças que estavam ocorrendo na sociedade norte-americana, com a difusão da fotografia, as novas formas de jornalismo, mostrando como a urbanização estava invadindo a vida privada das pessoas. Nesse artigo fizeram-se algumas distinções que permanecem até hoje, como por exemplo a consideração de que "the right to privacy does not prohibit any publication of matter which is of public or general interest", mas que ela permite a proibição em situações "que digam respeito à vida privada, hábitos, atos e relações de um indivíduo, e que não tenham conexão adequada com sua aptidão para um cargo público". Também referiu que "todos os homens têm o direito de manter afastado da curiosidade popular algumas coisas, seja na vida pública ou na privada", sendo que "a veracidade da matéria publicada não vale como defesa válida", como tampouco "a falta de malícia do editor".

Muitas vezes a proteção do direito à privacidade se dá a posteriori, após a sua violação pela via da responsabilidade civil, por exemplo. Nos Estados Unidos, em outro famoso artigo de sessenta anos atrás, Prosser (1960, p. 383) identificou quatro civil torts (atos ilícitos civis) relacionados à privacy: violação do direito a ser deixado só; revelação pública de informações privadas; publicização de dados equívocos que colocam alguém sob uma "false light", deturpando sua imagem ou identidade; apropriação do nome ou aparência alheia.

Mas, no ambiente americano, com exceção dos dois artigos acima citados, foi a jurisprudência que mais impactou a noção de privacy, invocada em processos de naturezas variadas - envolvendo garantias processuais penais, direitos de liberdade, direitos reprodutivos, aborto, comportamento sexual, casamento homossexual, direito de família, como será visto a seguir.

\section{A PRIVACY RECEPCIONADA PELA JURISPRUDÊNCIA NORTE-AMERICANA}

Oitenta e três anos depois do artigo precursor de Brandeis e Warren, J. Blackmun, ao julgar o caso Roe v. Wade, admitiu que a Constituição não menciona expressamente o right of privacy, mas referiu que a Suprema Corte reconhecia que a garantia de algumas zonas de

privacy of no citizen shall be infringed"). Mesmo quando a privacidade não é diretamente mencionada nos textos constitucionais, inúmeras cortes de justiça reconheceram uma proteção constitucional implícita ao direito à privacidade, como é o caso dos Estados Unidos, Canadá, França, Alemanha, Japão e Índia - isso sem falar de uma infinidade de leis, em um sem-número de países, que igualmente protegem tal direito. Também no plano supranacional, não se pode olvidar que a Declaração Universal dos Direitos do Homem, da ONU, de 1948, afirma que "no one shall be subjected to arbitrary interference with his privacy, family, home or correspondence..", ao passo que a Convenção Europeia de Direitos Humanos, de 1950, igualmente prevê que "everyone has the right to respect for his private and family life, his home and his correspondence" (SOLOVE, 2008, p. 3/4).

${ }^{11}$ Roscoe Pound, decano da Harvard Law School, referiu que esse artigo acrescentou um novo capítulo ao direito norteamericano (nothing less than adding a chapter to our law) (STRUM, 2002, p. 637). SOLOVE (2008, p. 15/16) referiu ser este artigo considerado o mais influente artigo doutrinário de todos os tempos, tendo pautado a discussão sobre a privacy, nos Estados Unidos, durante todo o século XX.

Revista de Direito Brasileira | Florianólopis, SC | v. 25 | n. 10 | p. 414-440 | Jan./Abr. 2020 
privacidade podia ser extraída da Constituição. ${ }^{12}$ Isso porque, em variados contextos, a Corte ou alguns de seus integrantes identificaram raízes daquele direito na Primeira Emenda (caso Stanley v. Geórgia, de 1969), na Quarta e na Quinta Emenda (casos Terry v. Ohio, de 1968, Katz v. United States, de 1967, Boyd v. United States, de 1886, Olmstead v. United States, de 1928), nas penumbras do Bill of Rights (caso Griswold v. Connecticut, de 1965), na Nona Emenda (voto concorrente de J. Goldberg, no caso Griswold), ou no conceito de liberdade garantido pela primeira seção da Décima Quarta Emenda (caso Meyer v. Nebraska). A esta diversidade de possíveis fundamentos constitucionais para a proteção da privacy corresponde uma enorme variedade de situações fáticas que foram decididas à luz de noções distintas de privacidade.

As próximas seções serão dedicadas à análise dos mais relevantes casos envolvendo a discussão da privacy, na jurisprudência da Suprema Corte norte-americana. Seguir-se-á a ordem cronológica em que os casos apareceram. Na exposição, indicar-se-á inicialmente a situação fática, com exposição do contexto em que surgiu o caso e depois será analisado o julgamento, com indicação se foi unânime ou por maioria. A letra J. está para Justice, que é como são chamados os integrantes da Suprema Corte (equivalente aos nossos Ministros), e C.J. está para Chief Justice, como são denominados os Presidentes da Suprema Corte. ${ }^{13}$

\subsection{Meyer v. Nebraska (1923)}

Um dos primeiros casos em que a Suprema Corte norte-americana abordou o tema da privacidade foi o caso Meyer v. Nebraska, julgado em 1923. Na verdade, o caso não foi decidido com invocação da noção de privacy, mas sim com base no devido processo legal substantivo (BEEMAN, 2012, p. 110). Afirmou-se que uma lei de Nebraska interferia com a liberdade garantida pela XIV Emenda, cujo alcance iria muito além da liberdade de ir e vir. Todavia, foram fixadas algumas noções que posteriormente seriam retomadas para a definição de privacy.

Situação fática:

Robert Meyer fora processado e condenado por ensinar alemão numa escola luterana no Estado de Nebraska, tendo criado um método que utilizava uma edição alemã da bíblia, com o propósito de simultaneamente ensinar religião e o idioma alemão. Sua conduta violava uma lei estadual que proibia o ensino de idioma estrangeiro a alunos até a $8^{\text {a }}$ série escolar. Na verdade, no mesmo dia (04/06/1923) foi também julgado o caso Bartels $v$. Iowa, que reunia outros processos igualmente envolvendo proibição de ensino de outros idiomas: alguns Estados proibiam o ensino de qualquer idioma que não fosse o inglês ou línguas antigas, ao passo que uma lei do Estado de Ohio proibia o ensino tão somente do idioma alemão (WHITE, 2016, p. 529). A solução foi a mesma para ambos os casos.

Sendo os EUA um país de imigrantes, o objetivo dessa legislação era garantir que todos os residentes nos Estados Unidos aprendessem o inglês. Visava-se evitar o surgimento de guetos de imigrantes que se comunicassem em seu idioma materno, em detrimento da língua inglesa.

Mantida a condenação nas esferas estaduais da Justiça, Meyer conseguiu fazer com que seu caso fosse conhecido pela Suprema Corte.

\footnotetext{
12 Warren e Brandeis não estavam pensando apenas na violação da privacidade enquanto ilícito que justificasse um pedido de reparação de danos. Tratava-se de um verdadeiro "direito", a ser exercido em diversos contextos. Aliás, um ano após a publicação de seu artigo, a Suprema Corte (caso Union Pacific Railway Co. v. Botsford, de 1891) fez referência à privacy em um caso em que afirmou não ser possível compelir alguém a se submeter a um procedimento cirúrgico, decisão na qual foi citada a famosa frase do juiz Cooley (igualmente citado por Warren e Brandeis como tendo sido o primeiro a falar num direito a estar só): "the right to one's person may be said to be a right of complete immunity; to be let alone" (SOLOVE, 2008, p. 17).

${ }^{13}$ Para informações mais detalhadas sobre a estrutura e funcionamento da justiça federal norte-americana, explicando como são selecionados os casos e como ocorre o processo de julgamento, escolha do redator do acórdão (inexiste a figura de Relator previamente sorteado), v. FACCHINI NETO, Eugênio. Estrutura e funcionamento da Justiça norteamericana. Revista da Ajuris, v. 113, p. 147-179 (2009).
}

Revista de Direito Brasileira | Florianólopis, SC | v. 25 | n. 10 | p. 414-440 | Jan./Abr. 2020 


\section{Julgamento (7 X 2):}

Escrevendo pela maioria, J. McReynolds reverteu a condenação de Meyer. Fundamentou sua decisão não na Primeira Emenda (que garante a liberdade de religião e de expressão), mas sim na $\mathrm{V}$ e na XIV Emendas, invocando o devido processo legal substantivo. Afirmou a inconstitucionalidade da lei estadual, por violar o direito fundamental de liberdade dos pais de propiciarem aos seus filhos a educação que melhor entendessem. Consequentemente, quem se dispusesse a fornecer essa educação não estaria violando nenhuma lei.

Entendeu-se que, ainda que louvável a finalidade da norma, ela não era forte o suficiente para garantir a constitucionalidade dos meios para alcançá-la ("a desirable end cannot be promoted by prohibited means"). Afirmou-se, ainda, que a determinação legislativa sobre o que representa um adequado exercício do poder de fixar políticas públicas jamais é final ou conclusiva, pois está sempre sujeita a ser revista pelo Judiciário, à luz das previsões constitucionais (BEEMAN, 2012, p. 111).

Embora a ratio dessa decisão permanecesse esquecida durante décadas, ela ressurgiu nos anos sessenta (MURPHY, 1992, p. 544), quando se revestiu de dignidade constitucional o conceito de right to privacy (até então uma ideia vaga, embora conhecida desde final do século XIX, deduzida da tradição da Common Law).

A parte do acórdão que serviu de base para o posterior desenvolvimento da privacy, foi a seguinte: "Sem dúvida, [liberdade] significa não somente ausência de restrições corporais, mas também o direito da pessoa de contratar, de se envolver em qualquer das ocupações da vida, de adquirir conhecimento útil, de casar, de constituir um lar e criar filhos, de adorar a Deus de acordo com os ditames de sua própria consciência, e, de forma mais geral, de aproveitar oportunidades, tudo isso que é essencial para a busca ordenada da felicidade por homens livres" (t.n.) (HALL, WIECEK e FINKELMAN, 1996, p. 418).

Este caso jamais foi overruled e permanece "good law", como se costuma dizer. Após o julgamento do caso Meyer, no mesmo ano um congressista apresentou um projeto de lei visando tornar "american" o idioma oficial dos Estados Unidos. O projeto não foi aprovado, mas vários Estados aprovaram leis tornando o inglês a língua oficial em seus territórios (HARTMAN, MERSKY e TATE, 2004, p. 410).

Desde o caso Meyer, a Corte manteve orientação constante no sentido de que alguns aspectos da autonomia familiar constituem direitos fundamentais e que a interferência governamental somente é admitida se superar o teste do strict scrutiny. Essas liberdades incluem o direito de casar, o direito de manter a família unida, de criar os filhos de acordo com sua visão de mundo (CHEMERINSKY, 2015, p. 832). Note-se que no caso Bartels v. Iowa, julgado conjuntamente com o caso Meyer (companion case), J. Holmes divergiu, entendendo ser constitucional a lei, ressaltando o elevado valor de ter todos os americanos "falando uma língua comum" (speak a common tongue) (VILE, 2014, p. 419).

Dois anos mais tarde a Suprema Corte, no caso Pierce v. Society of Sisters, por unanimidade declarou a inconstitucionalidade de uma lei do Estado de Oregon, que exigia que as crianças entre oito e dezesseis anos frequentassem apenas escolas públicas. ${ }^{14}$ A desobediência à lei seria considerada uma contravenção penal. Excepcionavam-se apenas as crianças que já tivessem completado a oitava série, que fossem portadoras de deficiência física ou mental, ou que residissem muito longe de qualquer escola pública. Essa lei foi contestada judicialmente pela Society of sisters of the Holy names of Jesus and Mary, uma organização católica que mantinha várias escolas confessionais naquele Estado, além de duas outras escolas particulares e por uma escola militar

\footnotetext{
${ }^{14}$ A lei derivava de uma iniciativa popular, incentivada e patrocinada pela Ku Klux Klan e pela Oregon Scottish Rite Masons, dentro do contexto do temor da expansão do comunismo após a Primeira Grande Guerra. A ideia era que o Estado pudesse controlar a doutrinação das crianças no espírito anti-bolchevismo. Além disso, especialmente a Ku Klux Klan, além de seu notório racismo, também era frontalmente contrária à Igreja Católica e suas escolas confessionais (YUDOF, 2009, p. 275/276 e PATRICK, 2006, p. 260/261).
} 
para meninos (WHITE, 2016, p. 530). Entendeu-se, por unanimidade, que o governo não pode impor às crianças uma educação estandardizada, pois "uma criança não é uma simples criatura do Estado; aqueles que a criam e dirigem seu destino tem o direito - e o elevado dever - de identificar e prepará-la para obrigações adicionais"15 (t.n.). Aspecto importante que também foi analisado nesse caso dizia respeito à legitimidade de uma instituição de ensino para ajuizar uma demanda que, na verdade, buscava assegurar direitos dos pais dos alunos (TRIBE, 2000, p. 439). Esse caso jamais foi overruled e frequentemente ainda é citado.

Em 1927, a Suprema Corte estendeu a ratio do caso Meyer para estrangeiros residentes no Hawaii, matriculados em escolas que somente ofereciam instrução em japonês - trata-se do caso Farrington v. Tokushige (1927) (WHITE, 2016, p. 195).

\subsection{Olmstead v. United States (1928)}

Esse foi o primeiro caso decidido pela Suprema Corte, envolvendo a legalidade de gravações clandestinas e interceptações telefônicas. A composição conservadora da Corte naquele período refletiu-se no resultado do julgamento. Também foi o primeiro caso em que se aventou a ideia de que o direito à privacidade teria proteção constitucional. Embora essa percepção tenha ficado vencida por ocasião do julgamento, ela foi revigorada três décadas mais tarde.

Situação fática:

Desde o início do século XX, inúmeros Estados norte-americanos haviam proibido as intercepções telefônicas. Em 1927, mais de vinte Estados já haviam criminalizado tal prática, inclusive o Estado de Washington, onde Olmstead residia (BAST, 2002, p. 840). Não havia, porém, legislação federal a esse respeito.

Roy Olmstead era um ex-oficial da polícia do Estado de Washington, que havia abandonado sua carreira para se tornar um bem sucedido contrabandista de bebidas alcoólicas ${ }^{16}$ vindas do Canadá. Ele era considerado uma espécie de celebridade em Seattle, onde vivia. A imprensa local o chamava de "king of the rumrunners", "the booze baron", ou "the good bootlegger". Com seus barcos, ele trazia cerca de 200 caixas de bebidas por dia, o que lhe garantia um faturamento bruto entre 150 e 200 mil dólares - um expressivo valor para a época.

Em 1925 ele acabou sendo preso e condenado criminalmente por violar a National Prohibition Act. A condenação fora possível em razão da interceptação e gravação telefônica de suas conversas, feitas clandestinamente por agentes do FBI, a partir das linhas de sua empresa e das residências de quatro de seus subordinados (PATRICK, 2006, p. 253). A defesa invocava a quarta e quinta emendas constitucionais para invalidar a interceptação e, com isso, anular todas as provas dela derivadas. Além disso, alegava que os agentes federais deveriam observar a legislação do Estado onde atuavam, que proibia gravações telefônicas clandestinas.

\footnotetext{
${ }^{15}$ Em outro caso, todavia, sustentou-se que o direito dos pais de decidirem sobre aspectos da vida de seus filhos não era absoluto e que o governo poderia intervir para proteger as crianças. Tratava-se do caso Prince v. Massachusetts (1944), em que a Suprema Corte validou a aplicação da legislação trabalhista que vedava o trabalho de crianças, a uma situação em que uma criança de nove anos estava sendo orientada e dirigida por seus pais para solicitar doações para a igreja das Testemunhas de Jeová. Sustentou-se que a proibição do trabalho infantil incluía também hipóteses em que a atividade estivesse sendo supervisionada pelos próprios pais, mesmo para fins religiosos (CHEMERINSKY, 2015, p. 843/844).

${ }^{16}$ Lembrando-se que em 1919 entrou em vigor a XVIII Emenda à Constituição norte-americana, que proibiu a produção, venda, transporte e importação de bebidas alcoólicas em todo o território nacional. Tratava-se do que lá se chamava Prohibition, por aqui mais conhecida por "lei seca". A emenda originara-se de forte pressão das camadas religiosas mais conservadoras da sociedade norte-americana. Evidentemente que tal norma nada mais fez do que empurrar para a ilegalidade toda a atividade de venda e transporte de bebidas alcoólicas, fabricadas clandestinamente ou contrabandeadas ilegalmente. Diante do seu total fracasso e do fato de que tal norma permitiu o surgimento e o fortalecimento de inúmeras redes criminosas, além da disseminação da corrupção por vários segmentos dos três poderes, referida emenda foi revogada pela Emenda XXI, em 1933.
}

Revista de Direito Brasileira | Florianólopis, SC | v. 25 | n. 10 | p. 414-440 | Jan./Abr. 2020 
Várias companhias telefônicas intervieram na condição de amici curiae, alegando que o objetivo da telefonia era "possibilitar que duas pessoas distantes conversassem em particular, como se estivessem na intimidade do lar ou do escritório de uma delas", estando as linhas telefônicas à exclusiva disposição das mesmas. Assim, qualquer pessoa que interceptasse a ligação, "estaria violando os direitos de propriedade daquelas pessoas, bem como os da companhia telefônica" (HARTMAN, MERSKY e TATE, 2004, p. 347).

\section{Julgamento (5 x 4):}

Uma maioria apertada dos Justices manteve a condenação. A maioria entendeu que tal conduta não violava a IV Emenda, pois não tinha havido busca, nem apreensão, muito menos invasão da residência ou do escritório do acusado. Afirmou-se que a linguagem da IV Emenda referia apenas "persons, houses, papers, and effects" e não poderia ser estendida para abranger também fios telefônicos (VILE, 2014, p. 340, e, para uma visão crítica, TRIBE, 2000, p. 53, n. 15).

Holmes e outros colegas divergiram. Em um trecho de seu voto dissidente, Holmes afirmou que "devemos ter em mente duas coisas igualmente desejáveis, mas que não podemos ter concomitantemente, o que nos compele a fazer uma escolha. É certamente desejável que os delinquentes sejam descobertos e punidos e que toda e qualquer prova existente seja utilizada para tal fim, mas também é desejável que o governo não se utilize de provas obtidas mediante um crime. (...). É preciso escolher e, quanto a mim, prefiro que alguns delinquentes escapem da justiça do que permitir que o governo aja de forma ignóbil" (HOLMES, 1975, p. 145/147). Holmes descreveu o envolvimento do governo (através do FBI) em gravações clandestinas como sendo um "negócio sujo" ("dirty business"). ${ }^{17}$

Mas a divergência mais famosa e mais substancial foi a de Brandeis, que além de acompanhar a divergência de Holmes, redigiu um voto muito mais contundente e profundo. Estava ele destinado a tornar-se célebre e repetidamente invocado nas décadas seguintes. Nas suas palavras: "Os criadores da nossa Constituição comprometeram-se a garantir condições favoráveis à busca da felicidade. Eles reconheceram o significado da natureza espiritual do homem, de seus sentimentos e de seu intelecto. Eles sabiam que apenas uma parte da dor, prazer e satisfação da vida é encontrada nas coisas materiais. Eles procuraram proteger as crenças, pensamentos, emoções e sensações dos americanos. Reconheceram-lhes, contra o governo, o direito de serem deixados a sós - o mais abrangente dos direitos e o direito mais valorizado pelos homens civilizados ("the right to be let alone - the most comprehensive of rights and the right most valued by civilized men"). Para proteger esse direito, toda intromissão injustificável do Governo sobre a privacidade do indivíduo, quaisquer que sejam os meios empregados, deve ser considerada uma violação da Quarta Emenda" (GREENBAUM, 1992, p. 153). ${ }^{18}$

\footnotetext{
${ }^{17}$ Brandeis foi ainda mais contundente sobre a necessidade de agentes públicos agirem rigorosamente dentro da lei: "A decência, a segurança e a liberdade exigem que as autoridades governamentais sejam submetidas às mesmas regras de conduta a que está sujeito o cidadão. Em um governo de leis, o governo existente estará em perigo se deixar de observar escrupulosamente a lei. Nosso governo é o professor poderoso e onipresente. Para o bem ou para o mal, ensina o povo inteiro pelo exemplo. O crime é contagioso. Se o governo se torna um violador da lei, gera menosprezo por ela; convida a todos a adaptarem a lei ao seu gosto; convida à anarquia. Entender que na gestão da persecução criminal o fim justifica os meios - entender que o governo pode cometer crimes a fim de assegurar a condenação de um criminoso particular traria consequências terríveis. Contra essa doutrina perniciosa, esta Corte deveria resolutamente mostrar sua face" (tradução livre) - in Olmstead v. United States, 277 U.S. 438 (1928), p. 485, disponível em https://supreme.justia.com/cases/federal/us/277/438/, acesso em 14/07/2019. Três décadas mais tarde, C.J. Warren ecoou essas palavras no seu voto, escrevendo por uma corte unânime, ao julgar o caso Spano v. New York (1959): “A polícia deve obedecer a lei ao fazer com que ela seja cumprida; ... no final, a vida e a liberdade podem ser tão ameaçadas pelos métodos ilegais usados para condenar os que se imagina serem criminosos, quanto pelos próprios criminosos reais" (em tradução livre) - in: Spano v. New York, 360 U.S. 315, p. 320, disponível em https://supreme.justia.com/cases/federal/us/360/315/, acesso em 15/07/2019.

${ }_{18}$ Uma ótima análise desse caso e outros envolvendo gravações e interceptações telefônicas é feita por ABRAHAM e PERRY (1998, p. 142/148).
}

Revista de Direito Brasileira | Florianólopis, SC | v. 25 | n. 10 | p. 414-440 | Jan./Abr. 2020 
Embora Brandeis sustentasse que a Constituição, como um todo, garantia aos cidadãos um espaço de privacidade, protegido contra interferências estatais, procurou ele extrair mais especificamente tal direito a partir da IV Emenda, que protege o cidadão contra "unreasonable searches and seizures" e na garantia da V Emenda, que protege o cidadão contra a autoincriminação (HALL e PATRICK, 2006, p. 151).

Em sua eloquente divergência, Brandeis chamou a atenção para o impacto que as novas tecnologias acarretam nas noções jurídicas, referindo que os instrumentos técnicos que permitiram as gravações não existiam quando da redação e promulgação da IV Emenda.

J. Owen Roberts divergiu por outras razões, mais afinadas com a argumentação exposta na intervenção dos amici curiae, afirmando que "the contracts between telephone companies and users contemplate the private use of the facilities employed in the service. The communications belong to the parties between whom they pass".

Em 1934 o Congresso proibiu, através do Federal Communications Act, a interceptação de qualquer comunicação e a divulgação de seu conteúdo (LAWRENCE, 1992, p. 606). Aplicando essa lei, a Suprema corte, em 1937, julgou o caso Nardone v. United States e considerou inconstitucional uma gravação clandestina feita pelo FBI e a excluiu do processo criminal. Na ementa, constou que "In view of the provisions of $\S 605$ of the Communications Act of 1934, 47 U.S.C. $\S 605$, evidence obtained by federal agents by tapping telephone wires and intercepting messages is not admissible in a criminal trial in the federal district court."19

O caso Olmstead foi overruled apenas em 1967, por ocasião do julgamento do caso Katz v. United States.

\subsection{NAACP v. Alabama (1958)}

Apesar daquela relativamente precoce decisão, pelas três décadas seguintes a Suprema Corte não voltou a se manifestar centralmente sobre o tema da privacy. Uma boa ocasião para tanto surgiu em 1958, no caso NAACP v. Alabama.

\section{Situação fática:}

O Estado de Alabama possuía uma legislação que procurava dificultar a existência de organizações que lutavam contra a segregação racial, como era o caso da NAACP - National Association for the Advancement of Colored People. Com base nessa legislação, a NAACP fora multada em U\$100.000, pela justiça do Alabama, por não ter entregue uma lista contendo os nomes de todos os seus filiados.

A entidade recorreu, então, à Suprema Corte, alegando que a entrega da lista dos nomes sujeitaria os seus membros a uma série de consequências potencialmente danosas, como demissão de seus empregos, assédios morais, violência, etc. Isso enfraqueceria o direito de associação, que seria fundamental, ainda que não previsto expressamente na Constituição.

Julgamento (9 X 0):

Neste caso, a Suprema Corte alterou uma antiga jurisprudência que reconhecia a autonomia legislativa dos Estados para regulamentar as associações, e passou a vincular o direito de associação ao direito constitucional de reunião, a ser analisado, portanto, a partir dos ditames constitucionais.

Escrevendo pela Corte, J. Harlan sustentou a existência de um direito fundamental à associação, extraído da Primeira Emenda, ainda que ali não constasse expressamente. De fato, a Primeira Emenda à Constituição norte-americana protege expressamente o direito/liberdade de reunião (right to assembly), mas nem ela nem as Constituições dos Estados se referem à liberdade de associação. Foi nesse caso que tal direito foi reconhecido, com status de direito fundamental (DOWNS, 2002, p. 43) e aplicado aos Estados-membros por força da XIV ${ }^{\mathrm{a}}$ Emenda. A Corte

19 Nardone v. United States, disponível em https://supreme.justia.com/cases/federal/us/302/379/, acesso em 13/07/2019.

Revista de Direito Brasileira | Florianólopis, SC | v. 25 | n. 10 | p. 414-440 | Jan./Abr. 2020 
entendeu que a lista dos associados estava tão vinculada ao direito destes de perseguir seus interesses de forma privada e de se associar para aumentar a eficácia de sua atuação, a ponto de se tratar de um direito constitucionalmente protegido (SLOTNICK, 1992, p. 572). Afirmou-se que somente o teste do strict scrutiny poderia determinar se e com que intensidade poderia o Estado restringir a liberdade de associação (HARTMAN, MERSKY e TATE, 2004, p. 412).

Forçar a NAACP a entregar o rol dos seus filiados acabaria por enfraquecer o direito fundamental de associação, pois era previsível que algumas pessoas deixassem de se associar à entidade, temendo retaliações em seus empregos. A Corte também argumentou que os membros da Associação que desejassem permanecer anônimos talvez jamais viessem a propor uma ação para discutir a constitucionalidade da norma, razão pela qual era a NAACP tinha legitimidade para fazêlo, representando seus associados (CHEMERINSKY, 2016, p. 114).

Harlan também referiu que mesmo que os fins buscados pelo legislador sejam legítimos, eles não podem ser alcançados através de meios tão amplos que possam invadir a esfera protegida da liberdade dos cidadãos. Através desse conceito de "overbroadness" ou "overbreadth" (amplitude exagerada), Harlan fixou a ideia de que os objetivos legítimos do legislador devem ser alcançados através dos meios mais restritos possíveis, quando limitarem direitos do cidadão (KOOPMANS, 2005, p. 119).

No seu voto, Harlan invocou decisões passadas da Corte em que ficara estabelecido o nexo entre freedom of speech and assembly, bem como entre freedom to associate and privacy.

Ao argumento do Estado de Alabama de que eventuais sanções impostas aos associados da NAACP seriam adotadas nas relações privadas dos associados (ou seja, por seus empregadores, por exemplo) e não por um órgão público (invocando, portanto, a state action doctrine, no sentido de que direitos fundamentais só podem ser opostos a entes públicos e não podem ser invocados nas relações particulares), respondeu Harlan destacando a interação entre a ação estatal e a atividade privada, pois os rumos daquela influenciam a atuação dos players nas relações privadas (VILE, 2014, p. 264/265). Afirmou-se, em suma, que o Estado seria responsável pelos danos que poderiam ser causados por particulares, caso ele retirasse o anonimato (TRIBE, 2000, p. 274).

Dois anos depois, em 1960, no caso Shelton v. Tucker, a Corte também derrubou uma lei de Arkansas que exigia dos professores de escolas públicas que revelassem as organizações às quais eles eram associados (HORWITZ, 1998, p. 34/35).

Essa decisão foi citada em casos posteriores que indicaram um direito fundamental à privacy, já que igualmente tal direito não se encontrava expresso na constituição. Começava-se, portanto, a abrir o leque dos direitos fundamentais, mesmo que não previstos na Constituição.

Nove anos mais tarde, a Suprema Corte voltou ao tema, ao julgar o importante caso Katz.

\subsection{Katz v. United States (1967)}

Foi através desse caso que se revogou o precedente do caso Olmstead, reconhecendo-se a inerente inconstitucionalidade das interceptações telefônicas não autorizadas judicialmente, mesmo que comprovassem a prática de um crime.

Situação fática:

Tratava-se de analisar a validade constitucional ou não de uma gravação clandestina feita pelo FBI, de conversas telefônicas do sr. Katz feitas a partir de uma cabine telefônica. Ele era suspeito de praticar ilegalidades (fazer apostas em outro Estado, por telefone, contrariando lei federal). Agentes federais, então, instalaram um gravador na parte externa de uma cabine telefônica que ele costumava utilizar, localizada próxima do seu local de trabalho (LaFAVE, 2009, p. 173).

Até então, o entendimento jurisprudencial era no sentido de que o grampeamento telefônico só seria ilícito se fosse precedido de invasão física no interior de um local constitucionalmente protegido (casa ou escritório), de acordo com precedentes da USSC (Olmstead v. United States, de 1928, e Silverman v. United States, de 1961) 
Katz alegou que seu grampeamento era ilegal, mas sua pretensão fora rejeitada pelas instâncias inferiores. Recorreu, então, à Suprema Corte.

Julgamento (7 X 1):

A USSC usou esse caso para alterar sua jurisprudência e fixar "a new standard" para a caracterização da noção de "search" (busca) da IV Emenda (SARAT, DOUGLAS E UMPHREY, 2012, p. 6): revogou o caso Olmstead e afirmou ser ilegal a escuta clandestina quando a parte tivesse uma razoável expectativa de privacidade (reasonable expectation of privacy) (FLETCHER, SHEPPARD, 2005, p. 262). Essa noção era destinada a deitar raízes no direito norte-americano, como teste para avaliar o merecimento da proteção da privacy, embora tenha sido restringida em casos posteriores, como será visto na sequência. Afastou, também, o entendimento de que a garantia da Quarta Emenda abrangia apenas violação física de espaços constitucionalmente protegidos (HARTMAN, MERSKY e TATE, 2004, p. 340).

Foi dito que "the Government's activities in electronically listening to and recording the petitioner's words violated the privacy upon which he justifiably relied while using the telephone booth".

J. Stewart afirmou que "a Quarta Emenda protege pessoas e não lugares" e que a "a presença do réu em uma cabine telefônica de vidro era irrelevante, uma vez que sua intenção não era excluir 'o olho invasivo' ('the intruding eye'), mas sim o 'ouvido não convidado'( 'the uninvited ear')".

Outro magistrado, $J$. Abe Fortas, observou que o direito à privacidade implicava a garantia a todos de poder viver suas vidas como escolhessem, "free from assault, intrusion or invasion, except as they can be justified by clear needs of community living under a government of law" (SOLOVE, 2008, p. 17).

O único voto divergente foi de J. Black, que na fase final de sua permanência na Suprema Corte tornou-se cada vez mais adepto de uma posição textualista (HORWITZ, 1998, p. 110). Black acusou seus colegas de serem "language-stretching judges", pretendendo "reescrever" a Constituição (ABRAHAM, 1998, p. 343). Segundo ele, não se tratava nem de uma busca (search), nem de uma apreensão (seizure), até porque não havia nada tangível a ser apreendido, nos termos previstos na IV Emenda (VILE, 2014, p. 341).

Katz overruled os casos Olmstead e Goldman v. United States $(1942)^{20}$.

Em razão do julgamento do caso Katz, o Congresso norte-americano aprovou o Omnibus Crime Control Act, proibindo interceptações, salvo se precedidas de mandado judicial ${ }^{21}$ ou com o $^{\circ}$ consentimento do envolvido (ROTH, 2002, p. 612).

Em caso posterior (California v. Ciraolo [1986]), por 5x4, a USSC restringiu um pouco a noção de razoável expectativa de privacidade. O caso envolvia a análise de considerar válidas ou não as imagens aéreas captadas de uma plantação de maconha dentro de um pátio cercado por um sólido muro de 3,3 metros de altura. Foi dito que isso não garantia a expectativa de privacidade, pois um policial poderia ter uma vista da plantação, desde que subisse no alto de um caminhão ou de um ônibus de dois andares. Reconheceu-se que é razoável a expectativa de privacidade de um cidadão, sobre as coisas que estão dentro de seu pátio cercado. Trata-se de uma expectativa daquilo que pode ser visto ao nível do solo. Todavia, ele não pode ter a expectativa de privacidade sobre

\footnotetext{
${ }^{20}$ Nesse caso, afirmou-se que "The use by federal agents of a detectaphone, whereby conversations in the office of a defendant were overheard through contact on the wall of an adjoining room, did not violate the Fourth Amendment, and evidence thus obtained was admissible in a federal court" - item 4 da ementa oficial, disponível no site https://supreme.justia.com/cases/federal/us/316/129/, acesso em 13/07/2019.

${ }^{21} \mathrm{O}$ título III da referida lei, intitulado "Wiretapping and Electronic Surveillance" especifica em que tipos de crime é possível gravação e interceptação telefônica, mediante prévia autorização judicial - sobre essa lei e sua aplicação, v. Abraham e Perry (1998, p. 145/146).
} 
aquilo que possa ser visto do céu, mesmo que se trate dos olhos de policiais treinados para identificar um pé de maconha. ${ }^{22}$

Em outros julgamentos, a Suprema Corte seguiu esclarecendo e restringindo seu conceito de expectativa de privacidade. Afirmou-se, por exemplo, que a expectativa de privacidade existe dentro da casa ou em outro edifício não aberto ao público, ou no carro. Mas tal expectativa inexiste em lugares abertos (open fields). Além disso, se uma área privada pode ser normalmente observada de fora - como, por exemplo, através de uma janela aberta, ou por meio de um helicóptero, não há que se falar em privacidade. A observação policial de algo, sem uso de instrumentos, a partir de um lugar onde possa legalmente estar, não constitui uma busca policial que precise observar os parâmetros da Quarta Emenda (caso Florida v. Riley, de 1989) (DAVIES, 2002, p. 720). No caso Hudson v. Palmer (1984), por escassa maioria de 5x4, a Corte afirmou que o precedente do caso Katz não se aplicava a um detento, no interior de um presídio. Foi afirmado que um detento não tem uma razoável expectativa de privacidade numa cela prisional e que, portanto, não poderia se opor a uma revista geral e completa que envolvesse também a sua cela (FAIR, 2009, p. 155).

Mas onde a noção de privacy revelou-se mais intensamente invocada foi em casos envolvendo o uso de contraceptivos e aborto. É o que veremos na série de decisões que serão analisadas na sequência.

\subsection{Griswold v. Connecticut (1965)}

O caso Griswold v. Connecticut é considerado o mais importante caso envolvendo a questão da privacy, principalmente em razão da opinion (voto) do J. Douglas, que procurou fundamentar constitucionalmente o direito à privacidade.

Quatro anos antes, ao julgar o caso Poe v. Ullman (1961), envolvendo a mesma lei do Estado de Connecticut que foi objeto do caso Griswold, J. Harlan já havia afirmado que ela violava a XIV Emenda, por afrontar o direito à privacidade do casal de decidir sobre questões íntimas, tais como métodos contraceptivos. Todavia, Harlan e outros três Justices ficaram vencidos, pois a maioria da Corte, invocando questões processuais, recusou-se a analisar a constitucionalidade ou não da lei de Connecticut. O voto vencido de Harlan, porém, foi uma das bases para a afirmação do direito constitucional à privacidade no caso Griswold.

Situação fática:

O caso era curioso e revelou-se importante. Diante de uma lei tida por todos como ridícula e anacrônica, mantida em vigor apenas por inércia ${ }^{23}$, tinha-se dificuldade de se encontrar base jurídica para a declaração de sua inconstitucionalidade (POSNER, 2008, p. 288).

Naquela época, legislação federal conhecida como Comstock Laws ${ }^{24}$ proibia a expedição, transporte interestadual e importação de materiais contraceptivos ou informações sobre eles. Vinte

\footnotetext{
${ }^{22}$ No caso, alguém havia feito uma denúncia anônima de que Ciraolo cultivava maconha em seu pátio cercado com altos muros. Diante disso, a polícia de Santa Clara, California, usou um avião para examinar o pátio de Ciraolo. Com base na observação, munida de um mandado judicial de busca e apreensão, encontrou 73 pés de maconha plantados no pátio. Condenado em primeiro grau, sua condenação foi anulada em segundo grau, sob o fundamento de que se tratava de violação da Quarta Emenda, invocando-se o caso Katz. A Suprema Corte, porém, por apertada maioria, entendeu inexistir uma legítima expectativa de privacidade no caso. Sobre esse caso, v. Hartman, Mersky e Tate (2004, p. 337/338).

${ }^{23}$ Sobre o tema, v. Calabresi (2015 [1982], p. 8, 9 e 11) e Whittington (2007, p. 120). Friedman (2002, p. 327/328) refere que em 1950, o Professor Vern Countryman, da Yale Law School, desejoso de desafiar a constitucionalidade da referida lei, foi até uma drug store em Hamden, Connecticut, e comprou um pacote de preservativos. Dali foi até uma delegacia de polícia, mostrou aos policiais o que havia comprado e exigiu que fosse preso, com intuito de posteriormente iniciar uma ação judicial desafiando a constitucionalidade da lei. Os policiais, porém, nada fizeram e Countryman desistiu de seu intento. Como se vê, nem os agentes encarregados de impor a observância das leis acreditavam na sua razoabilidade.

${ }^{24}$ Tratava-se de um conjunto de leis promulgadas a partir de 1873, que levaram o nome do seu proponente, Anthony Comstock, visando a "suppression of Trade in, and Circulation of, Obscene Literature and Articles of Immoral Use".

Revista de Direito Brasileira | Florianólopis, SC | v. 25 | n. 10 | p. 414-440 | Jan./Abr. 2020
} 
e dois Estados-membros também tinham 'little Comstock laws', dos quais o mais restritivo era o de Connecticut, que proibia de forma absoluta o uso de qualquer instrumento ou recurso visando o controle de natalidade (HORWITZ, 1998, p. 107).

Tratava-se de uma legislação estadual ${ }^{25}$ que remontava a 1879 , que criminalizava (com multa, detenção ou ambos) quem quer que "usasse droga, produto ou instrumento para prevenir a concepção", inclusive pessoas casadas, bem como proibia qualquer tipo de assistência a indivíduos que procurassem usar tais produtos ou instrumentos.

A diretora executiva (Estelle Griswold) e o diretor médico (Buxton, diretor clínico do hospital da Yale Medical School) do Planned Parenthood League of Connecticut foram processados com base na referida lei, por terem dado orientação, instrução e conselhos médicos a casais, sobre como prevenir a concepção.

Condenados nos três graus na justiça estadual a uma multa de cem dólares cada um, eles conseguiram fazer seu caso ser conhecido pela Suprema Corte, que teve de se debruçar sobre se havia ou não uma base constitucional para o direito à privacidade, já que tal direito não estava explicitamente mencionado na Constituição (HARTMAN, MERSKY e TATE, 2004, p. 291/294).

Julgamento (7 X 2):

Foi a primeira vez que a Corte sustentou a presença de um right to privacy como direito fundamental, "no less important than any other right ... reserved to the people", ainda que não tivesse base expressa na constituição (SCHWARTZ, 1993, p. 338). De fato, é sabido que a Warren Court expandiu as liberdades constitucionais tanto na esfera pública quanto em certas esferas da vida privada, especialmente quando envolvessem sexualidade e controle de natalidade. A Corte reconheceu que uma zona de privacidade imune da intrusão do governo era uma condição necessária para a auto-realização individual em uma sociedade democrática. Afinal, a democracia exige que os cidadãos retenham uma medida de autonomia quanto às escolhas privadas que eles desejem fazer em relação ao seus corpos (HORWITZ, 1998, p. 106).

Houve grande desacordo entre os Justices sobre como fundamentar tal direito: foram expressas quatro posições distintas.

J. Douglas, escrevendo por uma maioria de cinco membros, afirmou, em frase multicitada, que "specific guarantees ... have penumbras, formed by emanations from those guarantees that help give them live and substance" ("garantias específicas... têm penumbras, formadas pelas emanações daquelas garantias que ajudam a dar-lhes vida e substância"). Ele afirmou que as emendas I, III, IV, V e IX contêm zonas de penumbra das quais se pode extrair um direito fundamental à privacy (WHITE, 1998, p. 406). Em seu voto, enumerou diversas decisões da Suprema Corte que, ao aplicarem as referidas emendas, haviam identificado alguns redutos de privacidade. Referiu, por exemplo, o voto divergente de Brandeis no caso Olmstead v. United States, quando esse afirmou que "o direito de ser deixado só (right to be let alone) - o mais pleno dos direitos - é o direito que maior valor tem entre os homens civilizados" (GREENBAUM, 1992, p. 153). Referiu que o direito de formar associações não é mencionado nos textos constitucionais. Também não é mencionado o direito de educar os filhos na escola - pública, privada ou confessional - de livre escolha dos pais. Nem tampouco o direito de estudar uma determinada disciplina ou de aprender uma língua estrangeira. E, no entanto, todos esses direitos foram reconhecidos como fundamentais pela Suprema Corte, a partir de uma 'construção' da Primeira Emenda, em casos como Pierce v. Society of Sisters (1925) (para a livre escolha da escola), Meyer v. State of Nebraska (1923) (para o ensino de idioma estrangeiro) e DeJonge v. Oregon (1937) que reconheceu o direito de se associar a outros, ainda que o direito de associação não estivesse

Essa primeira lei criminalizava o uso do serviço postal americano para o envio de qualquer material envolvendo "obscenity, contraceptives, abortifacients, sex toys, personal letters with any sexual content or information, or any information regarding the above items." Outras leis se seguiram, ampliando ou alterando parcialmente seu conteúdo.

${ }^{25} \mathrm{Na}$ verdade, eram duas as leis. Uma que proibia penalmente o uso de contraceptivos e a outra que incriminava a conduta de quem de alguma forma auxiliasse outra pessoa a usar contraceptivos.

Revista de Direito Brasileira | Florianólopis, SC | v. 25 | n. 10 | p. 414-440 | Jan./Abr. 2020 
consagrado explicitamente na Constituição. Também referiu que a IV e V Emendas foram interpretadas no caso Boyd v. United States (1886) como protegendo o indivíduo contra toda e qualquer invasão governamental no "sagrado lar da pessoa e na sua vida privada". E ainda referiu o caso Mapp v. Ohio (1961), no qual se referiu que a IV Emenda assegura "um direito à privacidade não menos importante do que qualquer outro direito". Afirmou que "sem esses direitos periféricos, os direitos específicos seriam menos efetivos" (BEEMAN, 2012, p. 114/115).

Douglas via as leis em geral e a Constituição em particular como algo vivo (living, evolving rule book) que deve mudar à medida que a sociedade muda e à medida que situações não previstas vão surgindo, sendo um dever da Corte expandir a linguagem das normas para a proteção de novos direitos, quando a Justiça assim o exija (TRACHTMAN, 2016, p. 101).

Outros três Justices (Goldberg, Earl Warren e Brennan) apresentaram votos concorrentes, entendendo que o direito à privacy poderia ser protegido a partir do próprio direito à liberdade, já que "liberty protects those personal rights that are fundamental, and is not confined to the specific terms of the Bill of Rights". Goldberg acrescentou que "a linguagem e a história da Nova Emenda" fornecem forte suporte para a incorporação ${ }^{26}$ judicial de direitos adicionais "tão arraigados nas tradições e consciência de nosso povo, a ponto de poderem ser tidos como fundamentais". A IX Emenda estabelece que "a enumeração, na Constituição, de certos direitos, não pode ser invocada para negar ou excluir outros direitos que são retidos pelo povo", tendo ela sido redigida por James Madison, ante o temor de que a especificação de alguns direitos pudesse ser interpretada como uma vedação para a existência de outros não listados. Afirmou Goldberg que os direitos não atribuídos ao governo federal pertencem ao povo, segundo a Nona Emenda, e só podem ser restringidos se houver um "compelling state interest" (imperioso interesse público) ${ }^{27}$.

Justices Harlan e White também concordaram com o resultado final, mas apresentaram declaração de voto para fundamentar a decisão exclusivamente na cláusula do devido processo legal substantivo contido na XIV Emenda. A partir dessa cláusula eles entendiam ser possível extrair um direito à privacidade (PATRICK, 2006, p. 151).

Dois outros Justices (Black e Stewart) também entenderam que a lei de Connecticut era ridícula, mas que faltava à USSC base constitucional para a declaração da inconstitucionalidade, não se podendo transformar aquela Corte em uma convenção constitucional permanente ${ }^{28}{ }^{29}$

\footnotetext{
${ }^{26} \mathrm{~J}$. Brandeis foi um dos pioneiros na defesa da chamada incorporation doctrine, ou seja, a tese que defendia a aplicação aos Estados-membros do Bill of Rights contido na Constituição federal, através da due process clause da XIV Emenda. A primeira vez que aventou tal doutrina ocorreu no seu voto ao julgar o caso Gilbert v. Minnesota (1920). Alguns anos depois, no caso Gitlow v. New York (1925), sua posição foi acolhida pela Corte - sobre outras contribuições de Brandeis, v. Patrick (2006, p. 47/49).

${ }^{27}$ Koopmans refere que, posteriormente, a Corte passou a entender que a privacy não encontraria base constitucional na IX Emenda, mas sim na cláusula do due process da XIV Emenda (KOOPMANS, 2005, p. 213).

${ }^{28}$ Por vezes, juízes de instâncias inferiores que estejam de acordo com a ratio de uma decisão da Suprema Corte, tendem a expandir a tese jurídica para além da situação prevista no primeiro caso. Foi o que ocorreu com o caso Griswold. Cinco anos após seu julgamento, uma three-judge federal district court invocou o precedente do caso Griswold para justificar a declaração de inconstitucionalidade de uma lei antiaborto do Texas. Os juízes entenderam que referida lei violava o direito à privacidade de uma grávida solteira de optar, durante o primeiro trimestre de sua gravidez, pelo aborto. Essa foi a origem do caso Roe v. Wade, que três anos mais tarde, em 1973, chegaria à Suprema Corte (CARP, STIDHAM e MANNING, 2015, p. 387).

${ }^{29}$ Embora o C.J. Earl Warren tenha votado com a maioria, na primeira reunião que os membros da Corte tiveram, para debater o caso internamente, após os debates orais, ele teria externado que "I can't accept a privacy argument", como também não poderia aceitar os argumentos do “equal protection, or use a 'shocking' due process standard'. Depois acabou se convencendo do contrário, a partir dos argumentos avançados por seus colegas, embora não tenha lavrado nenhum voto concorrente, limitando-se a aderir ao voto da maioria. Esclareça-se que o regular processo de julgamento na Suprema Corte começa com uma reunião fechada dos seus nove membros, que, de forma imotivada, aceitam ou não julgar um caso, através do chamado writ of certiorari. É necessário que quatro dos nove membros entendam que o caso é relevante o suficiente para ser apreciado pela Suprema Corte. Isso ocorrendo, o caso é admitido e será analisado no ano forense seguinte, no qual é marcada audiência para debates orais (oral arguments). Nos dias imediatamente seguintes aos debates orais, a Corte novamente se reúne a portas fechadas, só os Justices e sem a presença de qualquer
}

Revista de Direito Brasileira | Florianólopis, SC | v. 25 | n. 10 | p. 414-440 | Jan./Abr. 2020 
O caso Griswold também exumou a velha questão do substantive due process of law, que ficara desacreditado em matéria de regulação econômica. Nesse caso, porém, os Justices Harlan, White, Goldberg, Brennan e Warren a invocaram, entendendo tratar-se da melhor abordagem para estabelecer a validade de direitos não escritos (HALL, WIECECK e FINKELMAN, 1996, p. $520)^{30}$.

O caso Griswold foi o primeiro em uma série de casos constitucionais envolvendo direitos de privacidade e de aborto. A crítica mais incisiva ao caso referiu-se ao fato de a Corte ter protegido um direito não previsto na Constituição, agindo como se fora legislador. $\mathrm{O}$ caso revelou que a Corte, quando fosse o caso, estava disposta a ir além do texto constitucional para proteger direitos tidos como fundamentais, interpretando a Constituição como um living document, apto a ser adaptado diante da evolução da sociedade e dos avanços da tecnologia (HARTMAN, MERSKY e TATE, 2004, p. 2004, p. 294/295). Como refere McCann, o legado do caso Griswold e a discussão sobre o alcance da privacy passa pelo perene problema dos esforços da Suprema Corte para lidar com necessidades e valores sociais sempre cambiantes, a partir da invocação de um arcabouço jurídico antigo, criado para regular outros tipos de relações sociais (McCANN, 2009, p. 138).

A decisão no caso Griswold v. Connecticut reconheceu, portanto, que pessoas casadas tinham o direito constitucional à privacidade, estando livres da interferência governamental quanto à decisão de usar ou não contraceptivos, reconhecendo a inconstitucionalidade da legislação do Estado de Connecticut. ${ }^{31}$

Embora tenha continuado a defender o fundamento constitucional de um right to privacy, a Suprema Corte admite restrições ao mesmo. Nos casos Skinner v. Railway Labor Executives Association (1989) e National Treasury Employees Union v. Von Raab (1989), a Corte reconheceu a constitucionalidade de legislação federal que previa a realização de testes para detecção de uso de drogas em funcionários de ferrovia, mesmo sem mandado e sem suspeita razoável de consumo de droga. Entendeu-se que havia uma justificativa razoável de interesse público, que limitava o direito à privacidade do cidadão em face do governo (PATRICK, 2006, p. 272).

outra pessoa (nem mesmo funcionários), para discutir e deliberar. A partir da discussão e da votação, define-se a maioria. Dentre os membros da maioria, o Chief Justice escolhe o redator do acórdão. Nas semanas subsequentes, o redator redige e faz circular entre os gabinetes dos seus pares o esboço de seu voto. A partir das observações dos demais, eventualmente vai alterando, incluindo ou retirando argumentos, para tentar obter a maior adesão possível. Quem discordar pode redigir votos divergentes, ou quem concordar com o resultado, mas não com a argumentação, pode elaborar votos concorrentes (concurrences). A discussão ocorrida na câmara secreta não é reduzida a qualquer ata. Mas muitos Justices costumam tomar notas das discussões ali travadas, até para elaborar seus votos e tentar incorporar pontos de vista dos colegas, com vista a obter sua adesão - já que quanto mais monolítica a decisão, sem divergências ou concorrências, maior tende a ser a força futura do precedente. E alguns desses Justices, normalmente nas memórias que escrevem após sua aposentadoria, revelam algumas conversas desses bastidores. Foi o caso dos J. Douglas e Brennan, que posteriormente revelaram os bastidores dessa decisão - sobre isso, com reprodução de parte dos diálogos travados entre os justices na tarde de 2 de abril de 1965, v. Hall e Patrick (2006, p. 156/157).

${ }^{30}$ Refere Tushnet que o termo due process remonta à Magna Carta, onde aparece como "the law of the land". Com o passar do tempo, a expressão ganhou outro sentido nos Estados Unidos: governos podiam agir arbitrariamente e violar o devido processo legal se, por exemplo, agissem em favor de grupos particulares de interesse, em vez de atuar em favor do interesse público. Tratava-se do devido processo legal substantivo, invocado pela Suprema Corte nas primeiras décadas do século XX para declarar a inconstitucionalidade de um grande percentual da legislação econômica reformadora, com o que contribuiu para desacreditar o termo substantive due process of law. A partir de 1937 a Suprema Corte deixou de se envolver com temas econômicos e voltou sua direção para a proteção de direitos não econômicos. Ao tratar da privacy e do aborto, a Suprema Corte acabou ressuscitando as ideias de um devido processo legal substantivo (TUSHNET, 2005, p. 281).

${ }^{31} \mathrm{O}$ caso Griswold influenciou diretamente o julgamento do caso McGee v. Attorney General, julgado em 1974, pela Suprema Corte da Irlanda. Neste julgamento também foi reconhecido que o right to privacy abrangia também o direito constitucional de pessoas casadas de ter acesso a meios contraceptivos (JACKSON e TUSHNET, 2006, p. 196/202).

Revista de Direito Brasileira | Florianólopis, SC | v. 25 | n. 10 | p. 414-440 | Jan./Abr. 2020 
O direito de decidir livremente sobre usar ou não contraceptivos por pessoas casadas, afirmado no caso Griswold, foi estendido a pessoas não casadas no caso Eisenstadt v. Baird, em $1972^{32}$, como se passa a examinar.

\subsection{Eisenstadt v. Baird (1972)}

Definido, pelo caso Griswold, que pessoas casadas podiam livremente usar métodos anticonceptivos, por se tratar de assunto relativo à privacidade do casal, espaço livre de interferência estatal, faltava aprofundar essa ideia e estendê-la também a pessoas não casadas. $\mathrm{O}$ caso Eisenstadt v. Baird serviu para esse movimento, vinculando a privacy não ao casamento, mas sim à autonomia privada. O fundamento básico, porém, utilizado para julgar esse caso foi o princípio da igualdade (equal protection of the laws) (HILLIARD, 2004, p. 33).

Situação fática:

Uma lei do Estado de Massachusetts considerava crime a conduta de qualquer pessoa, exceto um médico ou farmacêutico devidamente registrados e autorizados, que entregasse um produto ou medicamento contraceptivo a pessoas não casadas.

William Baird foi inicialmente condenado pela justiça daquele Estado, porque, numa palestra sobre contracepção a um grupo de estudantes da Boston University, exibiu artigos contraceptivos e, ao final, doou uma espuma contraceptiva a uma mulher. ${ }^{33}$

Posteriormente, junto à justiça federal, conseguiu a desconstituição da condenação.

Autoridades daquele Estado recorreram à Suprema Corte, defendendo a legislação sob a alegação de que ela promovia a fidelidade marital e desencorajava o sexo pré-casamento.

Já Baird sustentava que a lei de Massachusetts discriminava tratamento de pessoas casadas e solteiras, violando o princípio da igualdade.

Julgamento (6 X 1):

No caso Griswold, como visto, invocou-se a privacy como algo inerente ao casamento. A dúvida que remanesceu foi se somente pessoas casadas poderiam invocar a privacy para afastar intrusões governamentais em questões tão íntimas quanto o uso de contraceptivos. Essa questão foi resolvida no caso Eisenstadt (WHITE, 1988, p. 449, e MALTESE, 2009, p. 94).

A maioria, ainda que com votos concorrentes, esposando razões parcialmente diversas, estendeu a zona da privacidade para além do casamento. Afirmou-se que o direito do indivíduo de tomar decisões sobre procriação não deriva da existência de uma relação matrimonial, mas sim da autonomia individual de qualquer um, casado ou solteiro.

J. Brennan, pela maioria, afirmou que "é direito do indivíduo, casado ou solteiro, de ser livre de indevida intrusão governamental em temas que tão fundamentalmente afetam uma pessoa, como a decisão de ter ou criar um filho". O direito ao controle reprodutivo foi então reconhecido como direito fundamental. Também referiu que "seria claramente desarrazoado deduzir que Massachusetts prescreveu gravidez e o nascimento de uma criança indesejada como punição por fornicação".

Novamente discutindo a questão sob a égide do direito à privacy, a Corte não firmou posição sobre onde localizar a proteção constitucional de tal direito. Afirmou-se que o direito à privacidade é inerente à Primeira, Quarta, Quinta e Nona Emenda. A importância do caso reside em ter estendido a privacidade para além do casamento, afirmando que o controle sobre a procriação é inerente à autonomia do indivíduo, pouco importando se casado ou não.

\footnotetext{
${ }^{32}$ A respeito da evolução jurisprudencial sobre a questão do aborto, v. o verbete "Abortion and Reproductive Decisons", redigido por HOFFER e HULL (2002, p. 1-4).

${ }^{33}$ Uma completa, embora sucinta, história da evolução do controle de natalidade e planejamento familiar nos Estados Unidos encontra-se em CRITCHLOW (2001, p. 77/78), bem como, mais aprofundadamente, em JACKSON e TUSHNET (2006, chapter 1 (p. 1 a 140).
} 
Alguns anos mais tarde, outro caso envolvendo contraceptivos chegou à Suprema Corte. Tratava-se de decidir se o entendimento consolidado no caso Eisenstadt aplicava-se também a pessoas menores de idade. Tratava-se do caso Carey.

\subsection{Carey v. Population Services Int'l - PPA (1977)}

A Suprema Corte usou esse caso para estender ainda mais a proteção da privacy em matéria de uso de contraceptivos.

Situação fática:

A PPA era uma empresa sediada em North Carolina que vendia produtos contraceptivos pelo correio e regularmente publicava propaganda nos jornais de New York. Não havia qualquer restrição quanto aos destinatários, no concernente à idade ou estado civil.

A empresa foi então enquadrada numa lei de $\mathrm{N}$. York que incriminava qualquer conduta que implicasse o fornecimento de contraceptivos a menores de 16 anos ou que fizesse propaganda de contraceptivos.

Uma "three-judge district court" declarou a lei inconstitucional. O Estado de N. York, pelo seu governador Hugh Carey, conseguiu levar o caso à Suprema Corte.

Julgamento (7 X 2) :

Em julgamento bastante dividido quanto aos fundamentos e conclusões, com vários votos concorrentes, a Corte afirmou que:

a) a proibição de distribuição de contraceptivos sem prescrição médica violava a cláusula do devido processo legal da XIV Emenda;

b) menores tinham direito à mesma proteção constitucional aplicável aos adultos;

c) os Estados tinham maior liberdade para regular atividades de menores do que a de adultos;

d) a proteção do right of privacy abrangia o direito de um indivíduo, casado ou solteiro, de estar livre de interferências indevidas do governo, quanto a decisões pessoais relativas a relações íntimas.

Um ano antes, no caso Planned Parenthood of Central Missouri v. Danforth (1976), a Suprema Corte já havia afirmado ser inconstitucional uma completa vedação de acesso ao aborto por menores. Afirmou-se que "os direitos constitucionais não amadurecem e se tornam magicamente invocáveis apenas quando se atinge a maioridade legal". 34

\subsection{Casuística posterior.}

Estabelecidos os fundamentos constitucionais sobre a privacy, ainda que permeados de divergências entre os diversos Justices sobre qual a mais adequada base normativa, sua aplicação mais relevante aconteceu nos casos julgados posteriormente, envolvendo questões relacionadas ao aborto e aos direitos dos homossexuais. De fato, talvez o caso mais controvertido de todos os tempos, na jurisprudência norte-americana, tenha sido Roe v. Wade, julgado em 1973, que considerou inconstitucional legislação estadual restritiva ao aborto. Este passou a ser entendido como possível, por opção da gestante, até o final do primeiro trimestre da gestação. Em casos posteriores, dentre os quais se destaca Planned Parenthood of Southeastern Pennsylvania v. Casey, julgado em 1992, essa fórmula foi alterada, mas sem que fosse revogado o precedente do caso Roe. Esse caso consolidou o critério do undue burden, já mencionado no caso Webster v. Reproductive Health Services (1989), no sentido de que as restrições legislativas não poderiam colocar um fardo/peso excessivo para as gestantes desejosas de optar por um aborto. Tal critério substituiu o

\footnotetext{
${ }^{34}$ Sobre os direitos das crianças e adolescentes na jurisprudência norte-americana, v. Harris (2002, p. 95/98).
}

Revista de Direito Brasileira | Florianólopis, SC | v. 25 | n. 10 | p. 414-440 | Jan./Abr. 2020 
critério da divisão rígida por trimestres, do caso Roe v. Wade. Ainda recentemente, no caso Whole Woman's Health v. Hellerstedt (2016), essa orientação foi mantida.

Há pouco mais de um mês, em 29 de junho de 2020, no caso June Medical Services L. L. C. et. al. V. Russo, Interim Secretary, Louisiana Department of Health and Hospitals ${ }^{35}$, a Suprema Corte considerou inconstitucional lei do Estado de Lousiana, que dificultava o exercício do direito ao aborto. Foi o primeiro julgamento da Corte sobre o tema após o Presidente Trump ter nomeado os dois últimos juízes conservadores. Uma das promessas da campanha eleitoral de Trump, como se sabe, fora no sentido de que nomearia juízes comprometidos com a revogação do precedente Roe v. Wade. Para surpresa dos observadores, o presidente da corte, o conservador John Roberts, votou ao lado dos juízes liberais (Breyer, redator do acórdão pela maioria, Ginsburg, Sotomayor, Kagan), invocando o precedente do caso Whole Woman's Health v. Hellerstedt. Como a lei de Louisiana era idêntica à do Texas, considerada inconstitucional há apenas quatro anos atrás, ele entendeu que não havia razão para estabelecer uma diferenciação, ainda que ele afirmasse discordar do precedente. Ambas as leis exigiam que as clínicas de aborto realizassem convênios para enviar as pacientes a um hospital de maior complexidade, caso houvesse um situado a menos de $50 \mathrm{~km}$. Estimava-se que a norma provocaria o fechamento de dois terços das clínicas de aborto. Os juízes conservadores Thomas, Alito, Gorsuch e Kavanaugh ficaram vencidos.

Também em uma outra série de casos, envolvendo direitos dos homossexuais, a noção de privacy foi invocada, ainda que de forma minoritária no caso Bowers v. Hardwick (1986), em que a Corte se recusou a reconhecer a inconstitucionalidade de uma lei do Estado da Geórgia que punia com penas de até vinte anos de reclusão a prática de atos homossexuais. Esse absurdo precedente, porém, foi expressamente revogado no caso Lawrence v. Texas (2003), com base, dentre outros fundamentos, no direito à vida privada. E em 2015, a Suprema Corte admitiu, no caso Obergefell v. Hodges, a constitucionalidade do casamento entre pessoas do mesmo sexo.

Essas séries de casos, porém, pela sua importância, estão sendo abordados em outros dois artigos separados, por razões de espaço.

\section{CONSIDERAÇÕES FINAIS}

Analisando-se os acórdãos da Suprema Corte sobre a privacy, percebe-se não ser fácil agrupar os casos em torno de alguma noção estruturante, pois os Justices invocam tal noção em uma variedade de casos relativamente pouco ligados entre si. E precisamente essa multiplicidade de aplicações tornou controverso o grau de proteção constitucional aplicável a ela. Com certo esforço, porém, algumas noções básicas podem ser extraídas da casuística da Suprema Corte. Dentre elas o fato de que a expressão "privado", em oposição a "público", significa um domínio protegido contra a interferência governamental. $O$ valor subjacente ao conceito, na tradição kantiana, é o de autonomia, ou seja, a faculdade de cada um de escolher, por si próprio, como quer viver sua vida. Por outro lado, a noção de privacy não implica necessariamente algo sigiloso, pois muitas vezes invoca-se a noção de privacidade para a proteção de condutas que se quer exercer publicamente, como no caso do casamento entre pessoas do mesmo sexo. Já o elemento do segredo estará presente quando se trata de impedir a "invasão da privacidade" por parte de alguém, especialmente do governo (LEVINSON, 1992, p. 671/678).

Da leitura dos casos em que a Suprema Corte invocou a noção de privacy para julgar as mais diversas situações, percebeu-se que a noção fluída e polimorfa de privacidade, apontada pela doutrina e indicada no início deste artigo, contaminou a jurisprudência. De fato, como recordou J Blackmun, por ocasião do julgamento do caso Roe v. Wade, em 1973, a noção de privacy foi invocada pela Suprema Corte ao julgar casos envolvendo casamento (Loving v. Virginia, de 1967),

\footnotetext{
${ }^{35}$ Disponível no site da Supreme Court - https://www.supremecourt.gov/opinions/19pdf/18-1323_c07d.pdf, acesso em
} 06/08/2020.

Revista de Direito Brasileira | Florianólopis, SC | v. 25 | n. 10 | p. 414-440 | Jan./Abr. 2020 
procriação (Skinner v. Oklahoma, de $1942^{36}$ ), contracepção (Eisenstadt v. Baird, de 1972), relações familiares (Prince v. Massachusetts, de 1944) e criação e educação de filhos (Pierce v. Society of Sisters, de 1925 e Meyer v. Nebraska, de 1923) ${ }^{37}$.

Tal maleabilidade conceitual está ligada também à controvertida base constitucional da privacy. Referida noção não foi mencionada expressamente no texto constitucional. Ao longo das décadas, porém, diferentes Justices procuraram fundamentá-la na Primeira Emenda (caso Stanley v. Geórgia, de 1969), na Quarta e na Quinta Emenda (casos Terry v. Ohio, de 1968, Katz v. United States, de 1967, Olmstead v. United States, de 1928), nas penumbras do Bill of Rights (caso Griswold v. Connecticut, de 1965), na Nona Emenda (voto concorrente de J. Goldberg, no caso Griswold), ou no conceito de liberdade garantido pela primeira seção da Décima Quarta Emenda (caso Meyer v. Nebraska).

Fato é que, por mais amplas que sejam as dúvidas sobre a precisão do seu conceito e por mais controvertido que seja o seu embasamento constitucional - que outros Justices negam existir -, a privacy foi invocada para decidir importantes e polêmicos casos na jurisprudência da Suprema Corte dos Estados Unidos. Nos casos analisados, o direito à liberdade para decidir como educar os filhos foi acentuado no caso Meyer v. Nebraska; o direito a ser deixado só, sem intromissões indevidas do governo, foi reconhecido no caso Olmstead $v$. United States; a vinculação da privacy ao direito de associação, sem controle governamental, foi referida no caso NAACP v. Alabama; a existência de uma expectativa de privacidade, a ser protegida, foi afirmada no caso Katz v. United States; ao passo que o direito à autodeterminação dos indivíduos para decidirem sobre questões íntimas como planejamento familiar e uso de contraceptivos, foi reiterado nos casos Griswold v. Connecticut, Eisenstadt v. Baird e Carey v. Population Services Int'l. Foram referidos também outros casos, embora não analisados neste artigo, em que a noção da privacy foi invocada para proteger relacionamentos homossexuais, quer descriminalizando certas condutas, quer para autorizar casamentos entre pessoas do mesmo sexo.

Essa pluralidade de aplicações de uma mesma noção também está presente em outras jurisdições, é verdade, se lembrarmos que a privacy também foi invocada pela Corte Europeia de Direitos Humanos para afastar a criminalização de certas relações sexuais ${ }^{38}$, bem como para garantir o direito de um transexual de contrair casamento ${ }^{39}$. A privacidade também foi invocada para proteger a pessoa mesmo fora do recinto doméstico, como ocorreu com o caso Von Hannover, em que a Corte Europeia de Direitos Humanos proibiu a publicação de imagens da Princesa Caroline de Mônaco em atividade de lazer, com seus filhos na praia, fazendo compras e jantando com um namorado. Em todos esses casos, foi referido que mesmo pessoas conhecidas têm direito

\footnotetext{
${ }^{36} \mathrm{O}$ caso envolvia uma lei do Estado de Oklahoma (Oklahoma's Habitual Criminal Sterilization Act, de 1935), que definia criminosos habituais aquele que fosse condenado duas ou mais vezes por um crime punido com reclusão que denotasse "torpeza moral" (moral turpitude). Tais pessoas deveriam ser submetidas a uma esterilização compulsória. Skinner fora condenado uma vez por furto de galinhas e duas vezes por roubo. Estava cumprindo sua pena quando foi selecionado para se submeter a uma vasectomia. Ajuizou uma ação para evitar o procedimento. Perdeu na justiça estadual. Conseguiu fazer com que seu caso chegasse à Suprema Corte que, por unanimidade, considerou inconstitucional referida lei - sobre esse caso, v. HILLIARD (2004, p. 72/73 e 79/86).

${ }^{37}$ A esta lista poder-se-iam adicionar os casos Rochin v. California (1952) e Aptheker v. Secretary of State (1964). No primeiro, a Suprema Corte, por unanimidade, reverteu a condenação criminal de Rochin, por posse de substância entorpecente - morfina - que estava num invólucro em seu estômago, de onde foi extraído, contra sua vontade, por um médico, sob comando de agentes policiais (TALARICO, 2009, p. 303/304). No segundo, a Corte, por 6x3, reverteu uma decisão do Secretário de Estado que havia negado a emissão de passaporte a dois cidadãos americanos, membros da direção do Partido Comunista Americano, impedindo-lhes viajar ao exterior. Embora a Corte afirmasse que viajar ao exterior não seria um direito absoluto, o impedimento deveria levar em conta as particularidades do caso, como exemplificativamente o objetivo da viagem. Em 1958, ao julgar o caso Kent v. Dulles, a Suprema Corte já havia referido que o direito de viajar ao estrangeiro era parte da liberdade protegida pela Quinta Emenda (PRITCHETT, 2009, p. 14).

${ }^{38}$ Caso Dudgeon v. United Kingdom, de 1981.

${ }^{39}$ Caso Christine Goodwin v. United Kingdom, Ap. n. $28957 / 95$ (Grand Chamber), 2002-VI.
}

Revista de Direito Brasileira | Florianólopis, SC | v. 25 | n. 10 | p. 414-440 | Jan./Abr. 2020 
à privacidade, ainda que em espaços públicos, quando a atividade desenvolvida for nitidamente privada e sem qualquer interesse público ${ }^{40}$.

A noção de privacy naturalmente varia, conforme os ambientes culturais em que se dá a discussão. Essa é a razão pela qual ela tem um sentido e um peso diversos nos Estados Unidos frente à compreensão presente em países de tradição romano-germânica ${ }^{41}$. De acordo com a Corte Constitucional colombiana, por exemplo, com base na privacidade, o Congresso não pode criminalizar o consumo pessoal de entorpecentes ${ }^{42}$, nem punir a eutanásia envolvendo doentes terminais, se a vontade do doente nesse sentido for inequívoca ${ }^{43}$. Já nos Estados Unidos, a liberdade de imprensa tem enorme peso e, na ponderação com a privacy, muitas vezes leva a melhor - tanto assim que até o nome da vítima de um estupro pode ser publicado ${ }^{44}$.

Essa confusão conceitual, porém, não é apanágio da jurisprudência. Mesmo doutrinariamente o conceito de privacy é de difícil definição, pois é "exasperatingly vague and evanescent, often meaning strikingly different things to different people", em parte por ser uma noção de apelo emocional, abrangendo "a multitude of different "rights" (MILLER, 1972, p. 40/41). Solove (2008, p. 14-38), uma das maiores autoridades norte-americanas em estudos sobre a privacy, refere e analisa as várias concepções de privacy ("the right to be let alone", "limited access to the self", "secrecy", "control over personal information", "personhood", "intimacy") identificando suas limitações, referindo que na maioria das vezes essas concepções são demasiadamente estreitas, já que excluem temas e aspectos que não envolvem as características de

\footnotetext{
${ }^{40}$ Entre os casos jurisprudenciais de maior impacto envolvendo a violação ao direito à imagem merecem ser citados os casos envolvendo a Princesa Caroline de Mônaco (caso Caroline Von Hannover) (BVfG, 1999 e 2008). Referidos casos envolveram todas as esferas da jurisdição ordinária alemã, sua Corte Constitucional, além da Corte Europeia de Direitos Humanos. Embora Caroline não ocupe nenhum cargo ou função oficial no Principado de Mônaco, sempre foi perseguida pelos paparazzi, que a fotografaram em variadas situações. Ela tentou barrar, especialmente, três grupos de fotografias: 1) dela em companhia do ator Vincent Lindon, em um local reservado de um restaurante, obtidas com o uso de teleobjetiva; 2) dela com seus filhos, na praia e em outros locais públicos; 3) dela em locais públicos, mas em atividades privadas (fazendo compras, andando de bicicleta ou passeando). Na justiça ordinária, o Bundesgerichtshof (equivalente, grosso modo, ao nosso STJ) proibiu a divulgação do primeiro grupo de fotos, invocando a ideia de expectativa de privacidade. Para admitir a divulgação das demais fotos, baseou--se na antiga concepção germânica de "pessoa da história contemporânea". O BVfG (Bundesverfassungsgericht - Corte Constitucional alemã) expandiu a proibição para as fotos envolvendo os filhos da princesa. Relativamente às demais fotos, embora envolvessem cenas da vida privada de Caroline, a Corte Constitucional entendeu que mero entretenimento também é protegido pela liberdade de imprensa, desempenhando "um papel na formação da opinião", já que "muitos leitores obtêm informação que eles consideram importantes ou interessantes a partir da cobertura de entretenimentos pela imprensa". O caso foi parar na Corte Europeia de Direitos Humanos, que expandiu a proibição de publicação para todas as demais fotografias, reforçando a ideia da privacidade, mesmo de pessoas famosas. O que importaria seria o interesse público ou não da informação ou imagem, o que não ocorria no caso, segundo a corte europeia. Remetemos o leitor interessado nesse importante caso para Facchini Neto (2018, p. 294/295 e 303/303).

${ }^{41}$ Basta comparar, por exemplo, com a dogmática alemã, que distingue três implementações do direito geral de personalidade, a partir da jurisprudência do Tribunal Constitucional Federal alemão. Na síntese de Menke (2014, p. 210), é possível distinguir "o direito à autodeterminação (Recht der Selbstbestimmung), direito à autopreservação (Recht der Selbstbewahrung) e direito à auto-apresentação (Recht der Selbstdarstellung). O direito à autodeterminação (...) relacionada ao direito do próprio indivíduo de determinar/definir sua identidade abrangendo direitos como o do conhecimento da ordem biológica, o de ter um nome e uma orientação sexual e o de determinar o seu planejamento familiar (...). O direito à autopreservação garante ao indivíduo o direito de recolher-se para si e ficar só, sem a intromissão indevida de outros, tanto no aspecto social mais amplo quanto no espacial (...). O direito à autoapresentação possibilita que o indivíduo se insurja contra falsas, não autorizadas, degradantes ou deturpadas representações de sua pessoa, bem como protege das observações secretas e indesejadas de sua personalidade". Também a jurisprudência da Corte Europeia de Direitos Humanos interpreta a garantia da "vida privada", da Carta de Roma, como abrangendo um genérico "direito à autodeterminação", como se percebe da leitura de inúmeros de seus acórdãos, dentre os quais, S.H. e altri c. Áustria (j. em 03/11/2011, §80), Mcdonald c. Regno Unito (j. em 20/05/2014, §§46-47), Pretty c. Regno Unito (j. em 20/04/2002, § 61) - sobre isso, v. ZAGREBELSKY, CHENA e TOMASI (2016, p. 249).

${ }^{42}$ Corte Constitucional colombiana, Acórdão n. C-221/1994.

${ }^{43}$ Corte Constitucional colombiana, Acórdão n. C-239/1997.

${ }^{44}$ Suprema Corte dos Estados Unidos, caso Cox Broadcasting Corp. v. Cohn, de 1975.
}

Revista de Direito Brasileira | Florianólopis, SC | v. 25 | n. 10 | p. 414-440 | Jan./Abr. 2020 
relacionamentos íntimos. Mas também destaca que conceitos muito amplos, com capacidade de abranger todos os potenciais aspectos afetados pela noção de privacy, podem se revelar inoperantes, por serem demasiadamente vagos.

Essa ambiguidade e fluidez da noção de privacy não está ausente no cenário jurídico norteamericano. Ao contrário, como se viu de suas aplicações jurisprudenciais, ficou clara sua polimórfica invocação.

Em um mundo de cada vez maior exposição e transparência, com tecnologias que cada vez mais intensamente permitem que tudo se saiba de todos, pode-se ter dúvidas sobre o futuro da privacy. Todavia, pode-se dizer que seu passado foi, se não glorioso, certamente, ao menos, foi importante. O exame da jurisprudência da Suprema Corte envolvendo o tema, ressalta essa importância, pois alguns dos casos mais paradigmáticos - e polêmicos - daquela alta corte, foram decididos com a invocação da privacy. Resta saber quais serão os próximos passos.

\section{REFERÊNCIAS}

ABRAHAM, Henry J. (1998) The Judicial Process. $7^{\text {a }}$ ed. New York: Oxford University Press.

ABRAHAM, Henry J.; PERRY, Barbara A. (1998) Freedom and the Court - Civil Rights and Liberties in the United States. 7. ed. New York: Oxford University Press.

ALLEN, Anita (1988). Uneasy Access: Privacy for Women in a Free Society. Totowa/NJ: Rowman and Littlefield.

BAST, Carol M. (2002). Verbete "Wiretapping and Electronic Eavesdropping". In: HALL, Kermit L. (ed.). The Oxford Companion to American Law. New York: Oxford University Press.

BEEMAN, Richard (2012). Supreme Court Decisions. New York: Penguin Books.

BRANDEIS, Louis. WARREN, Samuel (1890). The Right to Privacy. In: Harvard Law Review, vol. IV, December 15, 1890, nº 5. Artigo, na sua versão eletrônica, disponível em:

http://groups.csail.mit.edu/mac/classes/6.805/articles/privacy/Privacy_brand_warr2.html, acesso em 30/05/2019.

CABRILLAC, Rémy (2017). Libertés et droits fondamentaux. 23 ${ }^{\mathrm{a}}$ ed. Paris: Dalloz.

CALABRESI, Guido (2015 [1982]). A Common Law for the Age of Statutes. Clark/New Jersey: The Lawbook Exchange.

CARP, Robert A.; STIDHAM, Ronald; MANNING, Kenneth L. (2015) Judicial Process in America. $9^{\text {th }}$ Ed. Los Angeles: Sage/Copress.

CHEMERINSKY, Erwin (2015). Constitutional Law - Principles and Policies. $5^{\mathrm{a}}$ ed. New York: Wolters Kluwer.

CHEMERINSKY, Erwin (2016). Federal Jurisdiction. $7^{\text {th }}$ Ed.. New York: Wolters Kluwer.

CRITCHLOW, Donald T. (2001). Verbete "Birth Control and Family Planning". In: BOYER, Paul S. (ed.). The Oxford Companion to United States History. New York: Oxford University Press. 
DAVIES, Thomas Y. (2002). Verbete "Search and Seizure". In: HALL, Kermit L. (ed.). The Oxford Companion to American Law. New York: Oxford University Press.

DOWNS, Donald A. (2002).Verbete “Assembly and Association”. In: HALL, Kermit L. (ed.). The Oxford Companion to American Law. New York: Oxford University Press.

ESPINOSA, Manuel José Cepeda (2012). Privacy. In: ROSENFELD, Michel; SAJÓ, András (ed.). The Oxford Handbook of Comparative Constitutional Law. Oxford: Oxford University Press.

FACCHINI NETO, Eugênio (2009). Estrutura e funcionamento da Justiça norte-americana. Revista da Ajuris, v. 113, p. 147-179.

FACCHINI NETO, Eugênio (2009-a). Prefácio da obra Direitos da Personalidade: disponibilidade relativa, autonomia privada e dignidade humana, de autoria de Fernanda Borghetti Cantalli. Porto Alegre: Livraria do Advogado.

FACCHINI NETO, Eugênio (2018). A proteção aquiliana do direito à imagem no direito comparado. Revista da AJURIS. Porto Alegre, v. 45, n. 144, Junho, p. 287/307.

FAIR, Daryl R. (2009). Verbete "Hudson v. Palmer". In: HALL, Kermit L.; ELY JR., James W. (ed.) The Oxford Guide to United States Supreme Court Decisions. Second Edition. New York: Oxford University Press.

FERRAZ JÚNIOR, Tércio Sampaio (1993). Sigilo de dados: o direito à privacidade e os limites à função fiscalizadora do Estado. Revista da Faculdade de Direito, Universidade de São Paulo, 88, 439-459. Recuperado de http://www.revistas.usp.br/rfdusp/article/view/67231

FLETCHER, George P.; SHEPPARD, Steve (2005). American Law in a Global Context - The basics. New York: Oxford University Press.

FRIED, Charles (1990). Privacy: A Rational Context, in: ERMANN, M.D.; WILLIAMS, M.B.; GUTIERREZ, C. (org.). Computers, Ethics, and Society. New York: Oxford University Press.

FRIEDMAN, Lawrence M. (2002). American Law in the 20th Century. New Haven: Yale University Press.

GAVISON, Ruth (1980). Privacy and the Limits of the Law. Yale Law Journal, vol. 89 (1980), disponível em https://digitalcommons.law.yale.edu/ylj/vol89/iss3/1, acesso em 31/07/2019. GREENBAUM, Jeffrey (org.) (1992). Giustizia costituzionale e diritti dell'uomo negli Stati Uniti - I giudici Warren e Burger. Milano: Giuffrè.

HALL, Kermit L., WIECEK, William M., e FINKELMAN, Paul (1996). American Legal History - Cases and Materials. 2a. ed. New York/Oxford: Oxford University Press.

HALL, Kermit L.; PATRICK, John J. (2006) The Pursuit of Justice - Supreme Court Decisions that Shaped America. New York: Oxford University Press.

HARARI, Yuval Noah (2015). Homo Deus - A Brief History of Tomorrow. London: Harvill Secker. 
HARRIS, Leslie J. (2002). Verbete “Children's Rights”. In: HALL, Kermit L. (ed.). The Oxford Companion to American Law. New York: Oxford University Press.

HARTMAN, Gary; MERSKY, Roy M.; TATE, Cindy L. (2004). Landmark Supreme Court Cases - The Most Influential Decisions of the Supreme Court of the United States. New York: Facts On File.

HAY, Peter (2010). Law of the United States. $3^{\text {rd }}$ ed. Paris: Dalloz.

HILLIARD, Bryan (2004). The U.S. Supreme Court and Medical Ethics. From Contraception to Managed Health Care. St. Paul/MN: Paragon House.

HOFFER, Peter Charles; HULL, N. E. H. (2002). Verbete "Abortion and Reproductive Decisons". In: HALL, Kermit L. (ed.). The Oxford Companion to American Law. New York: Oxford University Press.

HOLMES, Oliver Holmes (1975). Opinioni Dissenzienti. Milano: Giuffrè.

HORWITZ, Morton J. (1998). The Warren Court and the Pursuit of Justice. New York: Hill and Wang,.

JACKSON, Vicki; TUSHNET, Mark (2006). Comparative Constitutional Law. $2^{\text {nd }}$ Ed. New York: Foundation Press.

KOOPMANS, Tim (2005). Courts and Political Institutions - A Comparative View. Cambridge: Cambrigdge University Press.

LaFAVE, Wayne R. (2009). Verbete “Katz v. United States”. In: HALL, Kermit L.; ELY JR., James W. (ed.) The Oxford Guide to United States Supreme Court Decisions. Second Edition. New York: Oxford University Press.

LAWRENCE, Susan E. (1992). Verbete "Olmstead v. United States”. In: HALL, Kermit L. (ed.). The Oxford Companion to the Supreme Court of the United States. New York: Oxford University Press.

LEVINSON, Sanford (1992). Verbete "Privacy". In: HALL, Kermit L. (ed.). The Oxford Companion to the Supreme Court of the United States. New York: Oxford University Press.

MALTESE, John Anthony (2009). Verbete "Eisenstadt v. Baird". In: In: HALL, Kermit L.; ELY JR., James W. (ed.) The Oxford Guide to United States Supreme Court Decisions. Second Edition. New York: Oxford University Press.

McCANN, Michael W. (2009). Verbete "Griswold v. Connecticut”. In: HALL, Kermit L.; ELY JR., James W. (ed.) The Oxford Guide to United States Supreme Court Decisions. Second Edition. New York: Oxford University Press.

MENKE, Fabiano (2014). A proteção de dados e o novo direito fundamental à garantia da confidencialidade e da integridade dos sistemas técnico-informacionais no direito alemão. In: 
MENDES, Gilmar F.; SARLET, Ingo W.; COELHO, A. Z. P. (org.). Direito, Inovação e Tecnologia. Vol. 1. São Paulo: Saraiva.

MEULDERS-KLEIN, Marie-Thérèse (1992). Vie privée, vie familiale et droits de l'homme. Revue internationale de droit comparé. Vol. 44, n4, Octobre-décembre 1992, p. 767-794.

MILLER, Arthur R. (1972) The assault on privacy: Computers, data bank, and dossiers. New York: Signet.

MURPHY, Paul L. (1992). Verbete "Meyer v. Nebraska”. In: HALL, Kermit L. (ed.). The Oxford Companion to the Supreme Court of the United States. New York: Oxford University Press.

PAGALlO, Ugo (2008). La tutela della privacy negli Stati Uniti d'America e in EuropaModelli giuridici a confronto. Milano: Giuffrè Ed..

PARENT, William A. (1983). Privacy, Morality and the Law. Philosophy and Public Affairs, vol. 12.

PATRICK, John J. (2006). The Supreme Court of the United States. $3^{\text {rd }}$ ed. New York: Oxford University Press.

POSNER, Richard A. (2008). How Judges Think. Cambridge/USA: Harvard University Press.

PRITCHETT, C. Herman (2009). Verbete “Aptheker v. Secretary of State. In: HALL, Kermit L.; ELY JR., James W. (ed.) The Oxford Guide to United States Supreme Court Decisions. Second Edition. New York: Oxford University Press.

PROSSER, William L. (1960). Privacy. California Law Review, vol. 48, p. 383.

RODOTÀ, Stefano (2008). A vida na sociedade da vigilância - A privacidade hoje. Org., sel. e apres. de Maria Celina B. de Moraes. Trad. de Danilo Doneda e Lucia C. Doneda. Rio de Janeiro: Renovar.

ROTH, Mitchel (2002). Verbete "Police". In: HALL, Kermit L. (ed.). The Oxford Companion to American Law. New York: Oxford University Press.

SARAT, Austin; DOUGLAS, Lawrence; UMPHREY, Martha Merrill (2012). Introduction: Change and Continuity - Privacy and Its Prospects in the $21^{\text {st }}$ Century. In: SARAT, Austin; DOUGLAS, Lawrence; UMPHREY, Martha Merrill (ed.). Imagining New Legalities - Privacy and its Possibilities in the $21^{\text {st }}$ Century. Stanford: Stanford Law Books.

SCHWARTZ, Bernard (1993). A History of the Supreme Court. New York, Oxford University Press.

SLOTNICK, Elliot E. (1992). Verbete "National Association for the Advancement of Colored People v. Alabama ex rel. Patterson". In: HALL, Kermit L. (ed.). The Oxford Companion to the Supreme Court of the United States. New York: Oxford University Press.

SOLOVE, Daniel J. (2008). Understanding Privacy. Cambridge: Harvard University Press. 
STRUM, Philippa (2002). Verbete "Privacy". In: HALL, Kermit L. (ed.). The Oxford Companion to American Law. New York: Oxford University Press,.

TALARICO, Susette M. (2009). Verbete "Rochin v. California”. In: HALL, Kermit L.; ELY JR., James W. (ed.) The Oxford Guide to United States Supreme Court Decisions. Second Edition. New York: Oxford University Press.

TRACHTMAN, Michael G. (2016). The Supremes' Greatest Hits - The 44 Supreme Court Cases that most directly affect your life. New York: Sterling.

TRIBE, Laurence H. (2000). American Constitutional Law. Vol. I. 3 ed. New York: Foundation Press.

TUSHNET, Mark (2005). A Court Divided - The Rehnquist Court and the Future of Constitutional Law. New York: W. W. Norton \& Co.

VILE, John R. (2014). Essential Supreme Court Decisions - Summaries of Leading Cases in U.S. Constitutional Law. 16th ed. Lanham/Maryland: Rowman \& Littlefield.

WARREN, Samuel; BRANDEIS, Louis (1890). The Right to Privacy. Harvard Law Review, vol. IV, n. 5, (1890).

WESTIN, Alan F. (1970). Privacy and Freedom. New York: IG Publishing.

WHITE, G. Edward (1988). The American Judicial Tradition - Profiles of Leading American Judges. Expanded Edition. New York: Oxford University Press.

WHITE, G. Edward (2016). Law in American History. Vol II - From Reconstruction through the 1920s. New York: Oxford University Press.

WHITTINGTON, Keith E. (2007). Political Foundations of Judicial Supremacy. Princeton: Princeton University Press.

YUDOF, Mark G. (2009). Verbete "Pierce v. Society of Sisters". In: HALL, Kermit L.; ELY JR., James W. (ed.) The Oxford Guide to United States Supreme Court Decisions. Second Edition. New York: Oxford University Press.

ZAGREBELSKY, Vladimiro; CHENA, Roberto; TOMASI, Laura (2016). Manuale dei diritti fondamentali in Europa. Bologna: Il Mulino. 